\title{
Winter movements and habitat use of northern saw-whet owls at Assateague Island, Maryland
}

John Beaudry Churchill

West Virginia University

Follow this and additional works at: https://researchrepository.wvu.edu/etd

\section{Recommended Citation}

Churchill, John Beaudry, "Winter movements and habitat use of northern saw-whet owls at Assateague Island, Maryland" (1998). Graduate Theses, Dissertations, and Problem Reports. 904.

https://researchrepository.wvu.edu/etd/904

This Thesis is protected by copyright and/or related rights. It has been brought to you by the The Research Repository @ WVU with permission from the rights-holder(s). You are free to use this Thesis in any way that is permitted by the copyright and related rights legislation that applies to your use. For other uses you must obtain permission from the rights-holder(s) directly, unless additional rights are indicated by a Creative Commons license in the record and/ or on the work itself. This Thesis has been accepted for inclusion in WVU Graduate Theses, Dissertations, and Problem Reports collection by an authorized administrator of The Research Repository @ WVU. For more information, please contact researchrepository@mail.wvu.edu. 


\section{WINTER MOVEMENTS AND HABITAT USE OF NORTHERN SAW-WHET OWLS AT ASSATEAGUE ISLAND, MARYLAND}

\section{THESIS}

Submitted to the College of Agriculture, Forestry and Consumer Sciences of

West Virginia University

in Partial Fulfillment of the Requirements for the Degree of Master of Science

in

Wildlife and Fisheries Management

Division of Forestry

by

John B. Churchill

Morgantown, West Virginia

Nov. 11, 1998

Petra B. Wood, Chair

David F. Brinker

Dorothy C. Dunning

Robert C. Whitmore 


\section{TABLE OF CONTENTS}

ACKNOWLEDGEMENTS ................................................................

LIST OF TABLES ...................................................................

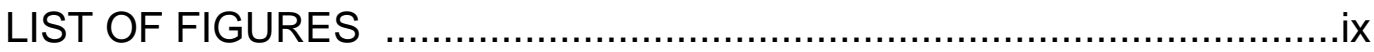

LIST OF APPENDICES ..................................................................

Chapter I. Literature Review and Introduction of Study

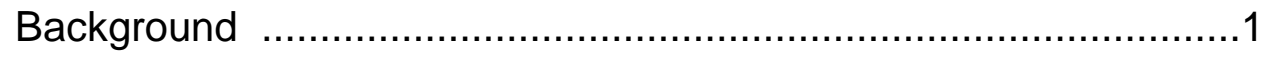

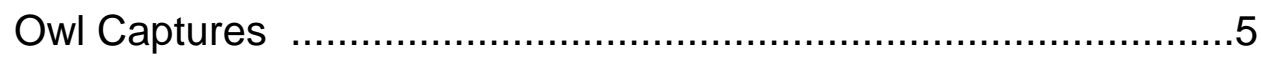

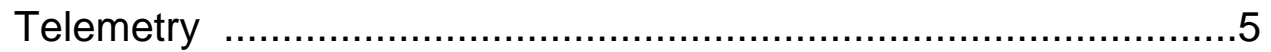

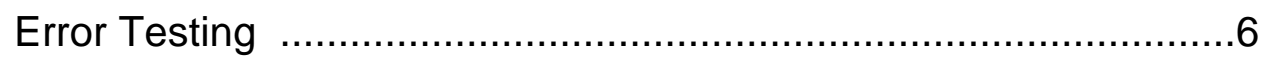

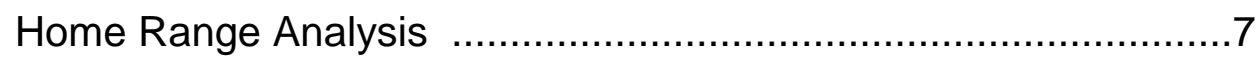

Comparison of Home Range Estimators ....................................

LITERATURE CITED ...............................................................11

Chapter 2. Winter Movements, Home Range and Habitat Use of Northern Saw-whet Owls at Assateague Island, Maryland

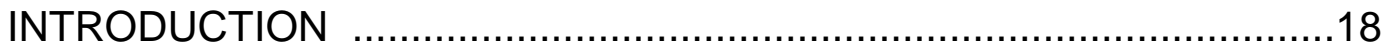

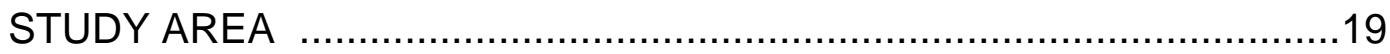

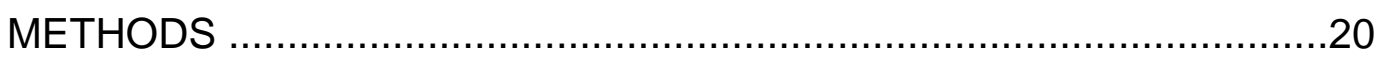

Owl Capture and Initial Measurements …................................20

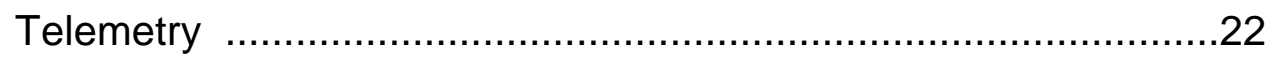

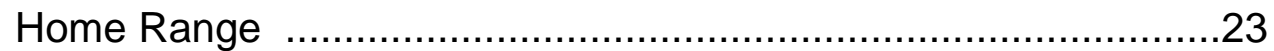

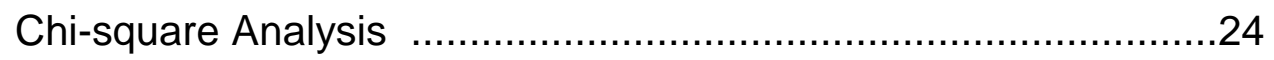

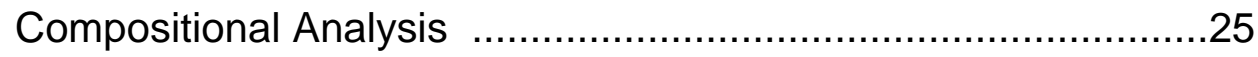

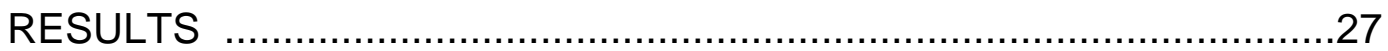




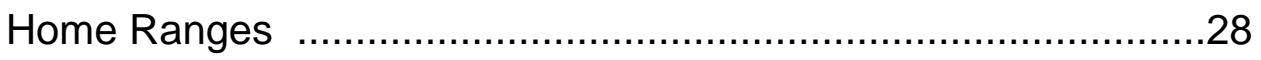

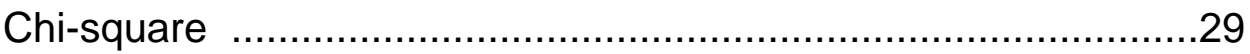

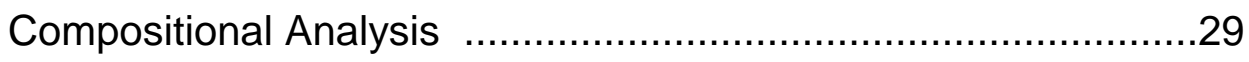

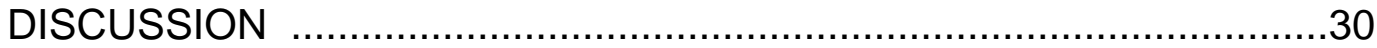

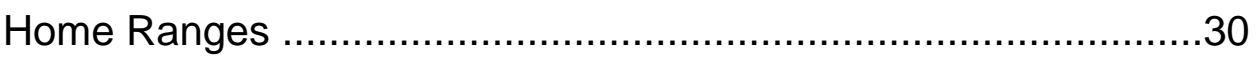

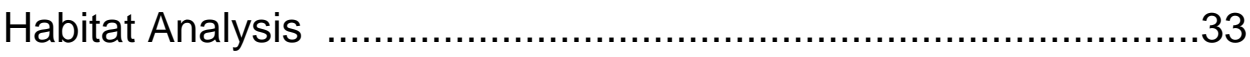

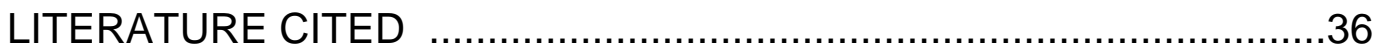

Chapter III. Diurnal Roost Site Characteristics of Northern Saw-whet Owls Wintering at Assateague Island, Maryland

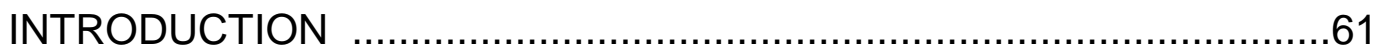

STUDY AREA AND METHODS ...................................................62

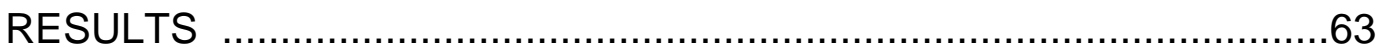

Movements Between Roosts ....................................................65

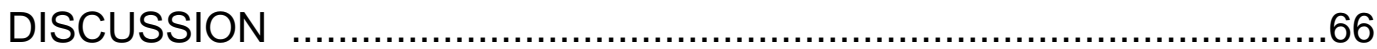

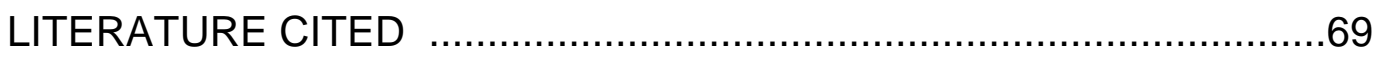

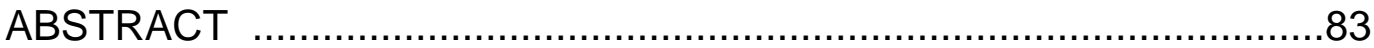




\section{ACKNOWLEDGEMENTS}

I wish to thank the Maryland Ornithological Society (MOS) for providing the primary source of funding for this project in 1996 and 1997. Additional support was provided by the West Virginia Cooperative Fish and Wildlife Research Unit (BRD, USGS) at West Virginia University, the Maryland Department of Natural Resources (Wildlife Division). Thanks to Carl Zimmerman from Assateague Island National Seashore for providing comfortable and affordable living accommodations both years.

This project was the brainchild of David F. Brinker who has banded Northern Saw-whet Owls at Assateague Island every Autumn since 1991. He and Dr. Matt Rowe from Appalachian State University, in Boone, North Carolina wrote the proposal for the MOS grant for the first field season. The idea for the project came about after winter banding for a capture-recapture study created an interest in movements of the owls. Both Dave and Dr. Rowe have given me a lot of good advice. Their experience working with these owls was a great benefit making Dave an important member of my research committee. Thanks also to Pace Cooper of Appalachian State University for helping me with transmitter attachment techniques.

I had the help of several short term field assistants over the two years. The most notable were Steve Huy and C. Smoot Major who helped with the owl banding on countless weekends and days off. Several employees of the Assateague Island National Seashore were of great assistance; Jesse Bellevance and Rose Railey helped with global positioning systems data, Mark Duffy and Chris Lea helped me obtain and interpret the vegetation map. Bill Hulslander also helped with the owl banding effort. Will Ravenscroft from the Natural Resources Analysis Center at West Virginia 
University helped me to get further up the learning curve associated with Geographic Information Systems (GIS).

I especially appreciate the assistance of my major advisor Dr. Petra Bohall Wood who always made time to answer questions and offered sound advice. Thanks for taking a chance on this out of state project. I also wish to thank the other members of my committee, Dr. R. C. Whitmore and Dr. D. C. Dunning, for their time and their guidance throughout my stay here at WVU. I appreciated having Dr. Robert Kenward review an earlier draft of the home range analysis. I also wish to thank Dr. J. T. Wassell for statistical advice and Erran Seaman for his help with program Kernel Home Range (KERNELHR).

l'd like to thank my family (especially my parents, John W. and Jule Churchill) for support of all kinds. Much of what kept me inspired was the emotional support of my fiancé Donna Kyle. Thanks to all of you for believing in me. 


\section{LIST OF TABLES}

Table 1-1. Total number of captures, average weights and standard deviations, and number of fall and winter recaptures of owls at Assateague Island, Maryland from Jan. 5 to Mar. 24, 1996 and Dec. 26, 1996 to Feb. 17, 1997.

Table 1-2. T-test results comparing the accuracy of Least Squares (LSE), Maximum Likelihood (MLE) and a robust variation of the Maximum Likelihood (MLE robust) estimators. Mean error values for LSE, MLE and robust MLE were 378.5, 277.9 and $267.0 \mathrm{~m}(\mathrm{n}=50)$ respectively.

Table 1-3. Ninety-five percent home range areas (in hectares) using fixed kernel, adaptive kernel, harmonic mean, and minimum convex polygon estimators and the number of locations used for the estimate (n). Fixed and adaptive kernel estimates were made using least squares cross validation (LSCV). OwI ID is the owl's radio transmitter frequency in $\mathrm{MHz}$.

Table 1-4. Ninety-five percent home range areas (in hectares) using fixed and adaptive kernel estimators. Estimates were made using the median bandwidth (148). Harmonic mean home ranges are not included here because they were not set to a standardized grid. A median grid size would have been too small for the larger home ranges. Owl ID is the owl's radio transmitter frequency in $\mathrm{MHz}$.

Table 2-1. Habitat composition in the Assateague Island study area, and in $30 \%$ and 95\% Northern Saw-whet Owl fixed kernel home range contours at Assateague Island, Maryland in 1996 and 1997.

Table 2-2. Ages, weights, dates of first capture and winter capture, and net stations telemetered Northern Saw-whet Owls were captured in at Assateague Island, Maryland in 1996 and 1997. Owl ID is the owl's radio transmitter frequency in MHz.

Table 2-3. Number of days spent tracking, dates tracked, number of locations estimated and number used for home range calculations after eliminating inaccurate locations of Northern Saw-whet Owls at Assateague Island, Maryland in 1996 and 1997. Owl ID is the owl's radio transmitter frequency in $\mathrm{MHz}$.

Table 2-4. Ninety-five percent fixed kernel home range areas (in hectares). Estimates were made using the median bandwidth $(148 \mathrm{~m})$. Owl ID is the owl's radio transmitter frequency in $\mathrm{MHz}$.

Table 2-5. Bi-weekly (per 2 weeks) Northern Saw-whet Owl 95\% fixed kernel home ranges in hectares. ID is the owl's radio transmitter frequency in $\mathrm{kHz}$ (above $150 \mathrm{MHz}$ ). 
Table 2-6. Fixed kernel home range overlap of Northern Saw-whet Owls at Assateague Island, Maryland in 1996 and 1997. Owl ID is the owl's radio transmitter frequency in $\mathrm{MHz}$.

Table 2-7. Habitat composition and $95 \%$ confidence intervals for habitat use (from 54 location points) and expected composition of Northern Saw-whet Owls at Assateague Island, Maryland in 1996 and 1997.

Table 2-8. Simplified ranking matrix (following Aebischer et al. 1993) for habitat preferences of Northern Saw-whet Owls radio-tracked at Assateague Island, Maryland in 1996 and 1997. The matrix was constructed from the comparison of 95\% home range with the habitat available in the study area without the use of the Aebischer et al. (1993) correction factor for small sample sizes. Each mean element in the matrix was replaced by its sign; a triple sign represents significant deviation from random at $P<$ 0.05 (student's $t$ distribution). Rank is from most avoided to most preferred (determined from the number of positive values in each row). Denominator habitats are in columns, while numerators are in rows.

Table 2-9. Mean log ratio differences (for all owls) used to construct the simplified ranking matrix (Table 2-10) and $t$ distributions from habitat used by Northern Saw-whet Owls at Assateague Island, Maryland in 1996 and 1997. Inverted ratios produced the 10 negative values in the simplified matrix.

Table 2-10. Average rank differences between habitat types (Johnson 1980) used by Northern Saw-whet Owls at Assateague Island, Maryland in 1996 and 1997. Negative numbers were preferred and positive numbers were avoided habitats.

Table 2-11. Comparison of Northern Saw-whet Owl home range sizes from Assateague Island, Maryland in 1996 and 1997 with results of other studies.

Table 3-1. Vegetation species used for roosts and frequency of use by Northern Sawwhet Owls at Assateague Island, Maryland in 1996 and 1997. Number of observations (obs.) indicates that owls were observed in the same roosts more than once. Owl ID represents the frequency of the attached transmitter (in MHZ).

Table 3-2. Characteristics of Northern Saw-whet Owl roost sites at Assateague Island, Maryland in 1996 and 1997. Sample size of 31 for some variables is due to one owl that roosted in two places within the same tree.

Table 3-3. Characteristics of Northern Saw-whet Owl random sites at Assateague Island, Maryland in 1996 and 1997.

Table 3-4. Averages and standard deviations of Northern Saw-whet Owl roost site characteristics by roost tree for myrtle and pine roosts at Assateague Island, Maryland in 1996 and 1997. 
Table 3-5. Comparison of Northern Saw-whet Owl roost site characteristics at Assateague Island, Maryland in 1996 and 1997 with results of other studies. 


\section{LIST OF FIGURES}

Figure 1-1. Increase in fixed kernel home range area between successive contour levels. Numbers in the legend are radio transmitter frequencies in $\mathrm{MHz}$.

Figure 2-1. The Assateague Island, Maryland study area and net stations used to capture Northern Saw-whet Owls in 1996 and 1997.

Figure 2-2. Thirty and $95 \%$ fixed kernel home ranges (using a set bandwidth of $148 \mathrm{~m}$ ) and habitat use of owl 150.178 at Assateague Island, Maryland in 1997.

Figure 2-3. Thirty and 95\% fixed kernel home ranges (using a set bandwidth of $148 \mathrm{~m}$ ) and habitat use of owl 150.217 at Assateague Island, Maryland in 1997.

Figure 2-4. Thirty and 95\% fixed kernel home ranges (using a set bandwidth of $148 \mathrm{~m}$ ) and habitat use of owl 150.247 at Assateague Island, Maryland in 1997. .52

Figure 2-5. Thirty and $95 \%$ fixed kernel home ranges (using a set bandwidth of $148 \mathrm{~m}$ ) and habitat use of owl 150.338 at Assateague Island, Maryland in 1996. .53

Figure 2-6. Thirty and 95\% fixed kernel home ranges (using a set bandwidth of $148 \mathrm{~m}$ ) and habitat use of owl 150.417 at Assateague Island, Maryland in 1996. .54

Figure 2-7. Thirty and 95\% fixed kernel home ranges (using a set bandwidth of $148 \mathrm{~m}$ ) and habitat use of owl 150.435 at Assateague Island, Maryland in 1996. .55

Figure 2-8. Thirty and $95 \%$ fixed kernel home ranges (using a set bandwidth of $148 \mathrm{~m}$ ) and habitat use of owl 150.458 at Assateague Island, Maryland in 1996. .56

Figure 2-9. Area of $95 \%$ home range overlap between owls 150.435 and 150.458 at Assateague Island, Maryland from Jan. 13 to Jan. 20, 1996.

Figure 2-10. Area of 95\% home range overlap between owls 150.217 and 150.247 at Assateague Island, Maryland from Jan. 12 to Mar. 2, 1997. .58

Figure 2-11. Area of $95 \%$ home range overlap between owls 150.178 and 150.217 at Assateague Island, Maryland from Jan. 8 to Mar. 21, 1997. .59

Figure 2-12. Area of $95 \%$ home range overlap between owls 150.178 and 150.247 at Assateague Island, Maryland from Jan. 12 to Mar. 2, 1997. .60

Figure 3-1. Three meter radius plot used for measurement of average canopy cover at Northern Saw-whet Owl roost sites at Assateague Island, Maryland in 1996 and 1997. Measurements were taken with a sighting tube at three points along each quadrant boundary line for a total of 12 measurements. 
Figure 3-2. Number of stems (in 2 categories of DBH) in $3 \mathrm{~m}$ plots centered on roost sites and random sites at Assateague Island, Maryland in 1996 and 1997. Asterisks indicate significant differences at alpha $=0.05$.

Figure 3-3. Roost site variables differentiating Northern Saw-whet Owl roost sites and random sites at Assateague Island, Maryland in 1996 and 1997. Asterisks indicate significant differences at alpha $=0.05$.

Figure 3-4. Ground cover composition in $3 \mathrm{~m}$ plots centered on roost sites and random sites at Assateague Island, Maryland in 1996 and 1997. No differences occurred between used and random sites $(P=0.05)$. The "other" category consisted of water, sand and grass. 


\section{LIST OF APPENDICES}

Appendix A. Calculation of distance between known and estimated locations. The distance between the known point (gps) and the estimated point (est.) is determined by the pythagorean theorem (square root of $\left(200^{2}+300^{2}\right)$ ). Numbers at the grid ticks represent Universal Transverse Mercator (UTM) meters.

Appendix B. Plant species associations grouped into distinct habitat types from the Assateague Island National Seashore vegetation map and percentages of each main habitat type within the study area.

Appendix C. Description of vegetation variables measured in 3 meter plots at roost and random sites at Assateague Island, Maryland in 1996 and 1997.

Appendix D. Description of vegetation variables measured only at roost sites at Assateague Island, Maryland in 1996 and 1997. 


\section{CHAPTER ONE}

\section{LITERATURE REVIEW AND INTRODUCTION OF STUDY}

\section{Background}

Four published studies exist, of radio-tracked Northern Saw-whet Owls (Aegolius acadicus) (American Ornithologists' Union 1998) from various seasons (Forbes and Warner 1974, Hayward and Garton 1984, Cannings 1987, Cockerel 1997), each with different objectives. Twelve Northern Saw-whet Owls were monitored and two nesting adult males, one non-breeding male and two fledglings were radio-tracked during the breeding season in montane coniferous forests and in the more abundant riparian deciduous woodlands in southern British Columbia (Cannings 1987). Minimum convex polygon (MCP) home ranges for the two nesting adult males were 142 and 159 ha based on 21.5 and 17.5 hours, respectively, of radio-tracking. One remained in a core area for 18.5 of 21.5 hours, while the other covered most of its home range regularly (Cannings 1987). One of the two radio-tracked males was in a riparian habitat which reflects their tendency to use wet habitats (Bent 1938, Johnsgard 1988, Palmer 1986, Cannings 1993). An MCP home range size of 113.6 ha was determined for a single Northern Saw-whet Owl in autumn near Minneapolis, Minnesota (Forbes and Warner 1974).

Methods other than radio-telemetry have been used to characterize home ranges. Winter and breeding habitat segregation of Boreal (Aegolius funereus) and Northern Saw-whet Owls was studied in Colorado (Palmer 1986). Northern Saw-whet Owls were located by listening for vocalizations. Estimated home range size was 78 ha 
(radius $0.5 \mathrm{~km}$ ) which was suggested to represent the optimum habitat available, although they probably used a larger area. In Wisconsin (Swengel and Swengel 1987), Northern Saw-whet Owls were located using auditory censusing (playing call tapes and listening for a response), voluntary calling surveys (listening without tapes), and visual observations. Home range was not calculated, but population densities of 5.0 calling Northern Saw-whet Owls $/ \mathrm{km}^{2}$ overall and $7.2 \mathrm{owls} / \mathrm{km}^{2}$ in forested areas were reported. They also measured roost height and roost tree height and compared sparsely and densely foliated trees, at 90 roost sites (Swengel and Swengel 1987). Continued research in Wisconsin characterizing 623 roosts at 20 sites, measured additional variables: limb length, trunk distance, roost orientation, tree $\mathrm{DBH}$, and presence/absence of the owl at the roost (Swengel and Swengel 1992).

Roost site selection of three telemetered Northern Saw-whet Owls at 15 roosts was studied in the River of No Return Wilderness in Idaho during spring and early summer (Hayward and Garton 1984); home range sizes were not reported. One study area consisted of Ponderosa Pine (Pinus ponderosa) and Lodgepole Pine (Pinus contorta), while Douglass Fir (Pseudotsuga menziesii) forest and open fir habitats including bunchgrass and mountain shrub were common in a second study area. They measured roost height, tree height, distance to trunk, distance to the nearest branch above and below the roost, cover above and below the roost, roost tree $\mathrm{DBH}$, minimum canopy height, and timber density in 5.2 and $11.4 \mathrm{~m}$ radius plots in four DBH size classes. They also measured vegetation using a line intercept sample of four $60 \mathrm{~m}$ lines and four $30 \mathrm{~m}$ lines around each roost. In southwestern Ohio, roost height and distance from the trunk relative to branch length were described for 15 owls (Randle and Austing 1952). 
Prey preferences of 15 radio-tracked Northern Saw-whet Owls were studied in the southern Appalachian Mountains of North Carolina (Cockerel 1997). Habitat from that study was primarily Red Spruce (Picea rubens) and Fraser Fir (Abies fraseri) with some Hemlock (Tsuga canadensis), Yellow Birch (Betula lutea) and Red Oak (Quercus rubra). Other studies of radio-tracked Northern Saw-whet Owls from Appalachian State University are ongoing (M. P. Rowe pers. comm.).

Northern Saw-whet Owls use a variety of habitats throughout their range. In the central and southern Appalachians (Simpson 1972), they typically inhabit spruce-fir communities (Red Spruce (Picea rubens) and two species of fir: Fraser Fir and Balsam Fir (Abies balsamea)). Using calling surveys, they were found year-round in the Great Balsam Mountains of North Carolina especially in a transition zone between Spruce-fir and hardwood communities, possibly due to a large number of small mammals in that zone. Recent studies in the Great Balsam Mountains (Milling et al. 1997) showed owl densities (of 1 owl per $2.7 \mathrm{~km}$ ) that were similar to those reported by Simpson (1972). In Washington, wintering Northern Saw-whet Owl habitat was composed of mostly big sagebrush (Artemisia tridentata), bluebunch wheatgrass (Agropyron spicatum) and cheatgrass (Bromus tectorum) with some fruit orchards interspersed throughout the study area. Roost height, tree height, distance to trunk, branch length, and distance from human activity were measured for eight owls at four roost sites in that study (Grove 1985). Northern Saw-whet Owls were found year-round in deciduous forests primarily in riparian areas of trembling aspen (Populus tremuloides) in Colorado (Palmer 1986). In areas where they coexist with Boreal Owls, they may be excluded by their larger congener at higher elevations in the spruce-fir zone (Palmer 1987, Cannings 1987, Hayward and Garton 1984). 
In the Great Lakes states, Northern Saw-whet Owls were found year-round in white pine (Pinus strobus), jack-pine (Pinus banksiana) - oak (Quercus spp.) woodlands and southern oak hardwoods in the Baraboo Hills of Wisconsin (Swengel and Swengel 1987). Northern Saw-whet Owls were found year-round in the Huron River Valley of Ann Arbor, Michigan, in second growth hardwoods such as pignut and shagbark hickory (Carya glabra and Carya ovata), swamp white oak (Quercus bicolor), red oak (Quercus rubra), white oak (Quercus alba), bur oak (Quercus macrocarpa) and American elm (Ulmus americana) as well as in plantations of red pine (Pinus resinosa), scotch pine (Pinus sylvestris), and Norway spruce (Picea abies) (Wilson 1938). Wintering Northern Saw-whet Owls were found in a tamarack (Larix laricina) bog and in red pine (Pinus resinosa) plantings with scattered ponds and areas of oak - hickory woods in Livingston County, Michigan (Mumford and Zusi 1958).

Northern Saw-whet Owls are banded every year at several coastal locations, including Cape May Bird Observatory, Cape May, New Jersey, Assateague Island, Maryland, and Cape Charles, Virginia (Duffy and Kerlinger 1992, Russell et al. 1993, Brinker et al. 1997, Whalen et al. 1997). Some owls banded at Cape May are occasionally recaptured at the other coastal banding stations. It is believed that most owls wintering in the region come from southern Canada and northern New England (Cannings 1993, Brinker et. al. 1997). Individuals banded at Assateague Island are not present during the breeding season. They typically start arriving in October and stay until late March (Brinker pers. comm.). Therefore, they make up a true wintering population. 


\section{Owl Captures}

There were a total of 66 captures over the two years of this study. Owl captures were very different in 1996 and 1997. Sixty-one Northern Saw-whet Owls were captured on 12 nights between January 5 and March 24, 1996 (Table 1-1). Several of the captures were owls that were originally captured in the fall or early winter. Foreign recaptures refers to owls originally banded somewhere other than Assateague Island, while telemetered recaptures are birds that were captured at Assateague Island, fitted with radio transmitters and later recaptured at Assateague Island. Radio transmitters were attached to five female owls in 1996. In 1997, only five owls were captured on eight nights between December 26 and February 17, all of which were used for telemetry. The first owl to be radio-tagged was subsequently recaptured 21 days later. I stopped running nets after the 17th of February because there were no captures on the last six attempts. I did not locate any owls for capture using tape playback. In 1997, two males and three females were telemetered.

\section{Telemetry}

In 1996, Assateague Island National Seashore personnel used global positioning systems (GPS) technology to estimate the coordinates of stations that I used for radio telemetry and error testing. GPS accuracy was estimated at approximately $5 \mathrm{~m}$. Stations were usually located near the road to facilitate moving quickly among them. The stations were used to estimate owl locations by triangulation in program OTA (Hoover 1994).

A null in the radio signal is a point where the signal drops off sharply. The bearing falling halfway between the nulls theoretically points towards the transmitter (Kenward 1987). When collecting the error data, I recorded both null bearings and one 
bearing aimed directly at the signal's source. I compared the accuracy of estimates made from single direct bearings with those from averages of the two nulls and compared each with estimates made by entering both nulls into the computer. The mean error distance was lowest when entering both null bearings directly, so I used this method for all location estimates.

\section{Error Testing}

Fence post tests are a way of determining the accuracy of telemetry location estimates. Transmitters are placed in a known location (e.g. on a fence post), and combinations of bearings from three or more stations are then used to estimate each transmitter's location by triangulation. I posted transmitters at some stations and recorded bearings from every combination of three stations that were within range of the posted transmitters to estimate their locations. Distances between location estimates and known (GPS determined) coordinates were calculated using the Pythagorean theorem $\left(A^{2}+B^{2}=C^{2}\right.$; where $A$ and $B$ are distances (in meters) between true and estimated $X$ and $Y$ coordinates). The resulting minimum hypotenuse $(C)$ is a measure of telemetry accuracy (Appendix A).

Fifty sample locations of planted transmitters were estimated using each of three triangulation location estimators (the least squares (LSE), maximum likelihood (MLE), and a robust version of the maximum likelihood estimator) in program OTA (Hoover 1994). The results of each method were then compared using matched pairs t-tests in SAS (SAS Institute Inc. 1987) (Table 1-2). Both maximum likelihood methods were significantly more accurate than the least squares method and the robust estimator was slightly more accurate than the standard MLE, so I used the robust MLE for all owl location estimates. The mean distance between true and estimated locations was 
$207.4 \mathrm{~m}(\mathrm{n}=151)$. This value included error from the collection of compass bearings and the subsequent triangulation estimates.

\section{Home Range Analysis}

Many procedures have been used to estimate animal home ranges. The minimum convex polygon method is one of the first and most traditionally used methods in spite of serious problems. It estimates the total area used instead of the area routinely used in normal movements (Jennrich and Turner 1969, White and Garrott 1990). Because the convex polygon includes all area between the outermost points, it may include areas not being used. Another procedure for estimating home range is the bivariate normal ellipse (Jennrich and Turner, 1969) which produces elliptical home ranges. It has not been widely used because of the poor fit of ellipses to telemetry locations. The harmonic mean method (Dixon and Chapman 1980) has frequently been used, although the method does not use a probability density function, which makes probability or percentage of use contours difficult to interpret. It is also greatly influenced by grid cell size (Kie et al. 1994) and there is no mathematically reasonable way to determine the optimum grid cell size for a data set.

Kernel methods are not greatly affected by grid cell size. They rely instead on a bandwidth or smoothing parameter $(\mathrm{h})$ for shaping and smoothing around location points. The kernel is a probability density that is applied to the data points in a sample and measured at grid intersections. The smoothing parameter is a constant in fixed kernel, but varies with density in adaptive kernel estimation. The "reference" method can be used to choose a smoothing parameter which produces accurate estimates when the data are unimodal but oversmooths when data are aggregated or multimodal. 
Both fixed and adaptive kernel estimates have shown a lower mean integrated square error (MISE) when the bandwidth was chosen using Least Squares Cross Validation (LSCV) (Worton 1995, Seaman and Powell 1996). The choice of an appropriate bandwidth or smoothing parameter has been shown to be critical to the conservation of error in kernel density estimates but the choice of fixed versus adaptive kernel has little effect (Worton 1995). It has been argued however, that along with the smoothing parameter, the choice of adaptive versus fixed kernel is important and the fixed kernel is the best choice for all distributions and sample sizes (Seaman and Powell 1996). I selected the fixed kernel method because it has been shown to estimate home range with a smaller associated error than other methods (Worton 1995, Seaman and Powell 1996).

I used the median optimum smoothing parameter as determined from the output from all seven original locational data sets to standardize smoothing across all individual owls. The median was used because the data were not normally distributed. The kernel home range program (Seaman and Powell 1991, Seaman et al. 1998) reports a bandwidth for both $\mathrm{X}$ and $\mathrm{Y}$ dimensions so the median bandwidth was determined using all 14 measurements. The median bandwidth in both the $X$ and the $Y$ dimensions of all owls was $148 \mathrm{~m}$, so all seven home ranges were re-calculated with the bandwidth (smoothing parameter) set manually to that value. This standardization was necessary to compare individual home ranges that were used for habitat compositions; home range area estimates computed by LSCV are better for calculating overall mean areas for groups of birds. 


\section{Comparison of Home Range Estimators}

Average $95 \%$ home range size of the seven owls calculated by LSCV, was 122.9 ha using the fixed kernel estimator, 164.8 ha using the adaptive kernel and 399.2 ha using the harmonic mean estimator (Table 1-3). Home range estimates were generally larger using the harmonic mean method. Ninety-five percent harmonic mean area estimates from owls 150.417 and 150.458 were both lower than adaptive or fixed kernel estimates possibly due to the lower sample sizes of those individuals. Home ranges calculated using the median optimum bandwidth (set bandwidth $=148 \mathrm{~m}$ ) averaged 103.5 ha (fixed kernel) and 141.1 ha (adaptive kernel) (Table 1-4). Home range areas that were used to determine the median optimum bandwidth (by LSCV) were larger than areas calculated using the set bandwidth for four out of seven individuals, and the averages were larger (Tables 1-3 and 1-4). The effect of the set bandwidth was to limit the sizes of larger home ranges and increase the sizes of smaller home ranges.

I estimated 20, 30, 40, 50,60, 70, 80, and 90 percent use contours to determine the appropriate contour to use as a core area. Wray et al. (1992) suggested using the largest increase in area between successive isopleths as a guideline for defining a useful core area. The increase in area shows the difference in intensity of use between consecutive areas. I intended to use the smaller of the two isopleths constituting the largest modal increase in area for all individuals to define core area. With my data however, the area of fixed kernel contours became larger with each successive isopleth from $20 \%$ to $90 \%$ (Figure 1-1). A $90 \%$ core area defeats the purpose of defining a core area so I chose the $30 \%$ utilization distribution (UD) for habitat analysis. Thirty percent contours appeared to represent a reasonable UD, being much smaller than the $95 \%$ area, but containing $30 \%$ of the area represented by all points. 
The failed attempt to determine core area from the largest increase in area of successive isopleths probably occurred because the fixed kernel method fit the location points too well. Since the fixed kernel method effectively eliminates areas that do not contain location points, there is very little increase between contours.

For description of individual home ranges, from this point on, I will refer to owls by their radio frequencies (e.g. the owl carrying radio frequency $150.178 \mathrm{MHZ}$ will be referred to as 178). Home ranges were largest using the harmonic mean method and smallest using the fixed kernel method which agrees with the findings of Seaman and Powell (1996) (Table 1-3). The larger 95\% home range area shown for owl 178 and the smaller area for owl 417 is likely to be a reflection of sample size since there were 241 location points for 178 and 36 and 39 points for 417 and 458 respectively. Owl 458 covered a large area in a short period of time, therefore its home range was large. Small samples calculated by the fixed kernel method have been shown to overestimate home range size (Seaman unpubl. data). This may explain harmonic mean 95\% area estimates for the two small sample individuals (417 and 458) that were smaller than their corresponding adaptive and fixed kernel estimates (Table 1-3). Calculation of fixed kernel home ranges using a set median bandwidth appears to be a reasonable way to standardize across individuals for subsequent use in analyzing habitat.

The lack of information about the wintering ecology of these owls and the paucity of home range and habitat information make this a valuable study. The potential of coastal barrier islands as Northern Saw-whet Owl habitat has not been well researched. Habitat use/availability studies have never been done for Northern Saw-whet Owls in spite of a fair amount of descriptive habitat information. Home range and habitat 
preference information from this study provides a baseline for future Northern Saw-whet Owl research.

The present study investigated home ranges, habitat use vs. availability and roost site characteristics of Northern Saw-whet Owls on a coastal barrier island. The potential of coastal areas as wintering habitat has not been well studied, though coastal shrub communities could represent important wintering habitats for Northern Saw-whet Owls (Loos and Kerlinger 1993). Questions such as, whether or not they are territorial in their wintering areas and whether or not they use multiple roosts have not been addressed.

\section{LITERATURE CITED}

American Ornithologists' Union. 1998. Check-list of North American birds. 7th ed., American Ornithologist's Union, Washington, D. C.

Bent, A. C. 1938. Life histories of North American birds of prey (part 2). Orders Falconiformes and Strigiformes. Bull. U.S. Natl. Mus. No. 170.

Brinker, D. F., K. E. Duffy, D. M. Whalen, B. D. Watts and K. M. Dodge. 1997. Autumn migration of Northern Saw-whet Owls (Aegolius acadicus) in the middle Atlantic and northeastern United States: what observations from 1995 suggest. Pp. 7489 in Biology and conservation of owls of the Northern Hemisphere. (J. R. Duncan, D. A. Johnson, and T. H. Nicholls, Eds.). U. S. Forest Service Gen. Tech. Report NC-190.

Cannings, R. J. 1987. The breeding biology of Northern Saw-whet Owls in southern British Columbia, Pp. 193-198 in Biology and conservation of northern forest owls (R. W. Nero, R. J. Clark, R. J. Knapton, and R. H. Hamre, Eds.). U.S. Forest Service Gen. Tech. Report RM-142.

Cannings, R. J. 1993. Northern Saw-whet Owl (Aegolius acadicus). in The birds of North America. (A. Poole and F. Gill, eds.). Acad. Of Nat. Scien., Philadelphia, Pennsylvania.

Cockerel, B. L. Jr. 1997. Prey preferences of the Northern Saw-whet Owl (Aegolius acadicus) in the southern Appalachian Mountains. M.S. thesis, Appalachian State Univ., Boone, North Carolina. 
Dixon, K. R. and J. A. Chapman. 1980. Harmonic mean measure of animal activity areas. Ecology 61:1040-1044.

Duffy, K. and P. Kerlinger. 1992. Autumn owl migration at Cape May Point, New Jersey. Wilson Bull. 104(2):312-320.

Forbes, J. E. and D. W. Warner. 1974. Behavior of a radio tagged Saw-whet Owl. Auk 91:783-795.

Grove, R. A. 1985. Northern Saw-whet Owl winter food and roosting habits in northcentral Washington. Murrelet 66:21-24.

Hayward, G. D. and E. O. Garton. 1984. Roost habitat selection by three small forest owls. Wilson Bull. 96:690-692.

Hoover, B. A. 1994. OTA radio telemetry analysis program. ftp://ftp.im.nbs.gov/pub/software/telem/ota/ ${ }^{*}{ }^{*}$ (4 files).

Jennrich, R. I. and F. B. Turner. 1969. Measurement of noncircular home range. Journal of Theoretical Biology 22:227-237.

Johnsgard, P. A. 1988. North American Owls; Biology and Natural History. Smithsonian Institution Press, Washington.

Kenward, R. 1987. Wildlife radio tagging: equipment, field techniques and data analysis. Academic Press, Orlando, Florida.

Kie, J. G., J. A. Baldwin and C. J Evans. 1994. Calhome home range analysis program: electronic user's manual. U. S. Forest Service, Pacific Southwest Research Station, Fresno, California.

Loos, G. and P. Kerlinger. 1993. Road mortality of Saw-whet and Screech-Owls on the Cape May peninsula. J. Raptor Res. 27:210-213.

Milling, T. C., M. P. Rowe, B. L. Cockerel, T. A. Dellinger, J. B. Gailes and C. E. Hill. 1997. Population densities of Northern Saw-whet Owls (Aegolius acadicus) in degraded boreal forests of the Southern Appalachians. Pp. 272-285 in Biology and conservation of owls of the Northern Hemisphere. (J. R. Duncan, D. A. Johnson, and T. H. Nicholls, Eds.). U. S. Forest Service Gen. Tech. Report NC190.

Mumford, R. E. and R. L. Zusi. 1958. Notes on movements, territory, and habitat of wintering Saw-whet Owls. Wilson Bull. 70:188-191.

Palmer, D. A. 1986. Habitat selection, movements and activity of Boreal and Saw-whet Owls. M. S. thesis, Colorado State University, Fort Collins. 
Palmer, D. A. 1987. Annual, seasonal, and nightly variation in calling activity of Boreal and Northern Saw-whet Owls. Pp. 162-168 in Biology and conservation of northern forest owls (R.W. Nero, R.J. Clark, R.J. Knapton, and R.H. Hamre, Eds.). U.S. Forest Service Gen. Tech. Report. RM-142.

Randle, W. and R. Austing. 1952. Ecological notes on Long-eared and Saw-whet Owls in southwestern Ohio. Ecology 33:422-426.

Russell, R. W., P. Dunne, C. Sutton and P. Kerlinger. 1993. A visual study of migratory owls at Cape May Point, New Jersey. Condor 93:55-61.

SAS Institute Inc. 1987. SAS/STAT users guide: version 6.03. SAS Institute Inc., Cary, North Carolina.

Seaman, D. E. and R. A. Powell. 1991. Kernel home range estimation program. North Carolina State University. Raleigh, North Carolina.

Seaman, D. E. and R. A. Powell. 1996. An evaluation of the accuracy of kernel density estimators for home range analysis. Ecology 77:2075-2085.

Seaman, D. E., B. Griffith and R. A. Powell. 1998. KERNELHR: a program for estimating animal home ranges. Wildl. Soc. Bull. 26:95-100.

Simpson, M. B. Jr. 1972. The Saw-whet Owl population of North Carolina's Southern Great Balsam Mountains. Chat 36:39-47.

Swengel, S. R. and A. B. Swengel. 1987. Study of a Northern Saw-whet Owl Population in Sauk County Wisconsin. Pp. 199-208 in Biology and conservation of northern forest owls (R.W. Nero, R.J. Clark, R.J. Knapton, and R.H. Hamre, Eds.). U.S. Forest Service Gen. Tech. Report RM-142.

Swengel, S. R. and A. B. Swengel. 1992. Roosts of Northern Saw-whet Owls in southern Wisconsin. Condor 94:699-706.

Whalen, D. M., B. D. Watts, M. D. Wilson and D. S. Bradshaw. 1997. Magnitude and timing of the fall migration of Northern Saw-whet Owls through the Eastern Shore of Virginia, 1994-1996. Raven 68:97-104.

White, G. C. and R. A. Garrott. 1990. Analysis of wildlife radiotracking data. Academic Press, San Diego, California.

Wilson, K. A. 1938. Owl studies at Ann Arbor, Michigan. Auk 55: 187-197.

Worton, B. J. 1995. Using Monte Carlo simulation to evaluate kernel-based home range estimators. J. Wildl. Manage. 59:794-800. 
Wray, S., W. J. Cresswell, P. C. L. White and S. Harris. 1992. What, if anything is a core area? An analysis of the problems of describing internal range configurations. Pages 257-271 in Wildlife telemetry: remote monitoring and tracking of animals. (I. G. Priede and S. M. Swift, Eds.). Ellis Horwood, New York, New York. 
Table 1-1. Total number of captures, average weights and standard deviations, and number of fall and winter recaptures of owls at Assateague Island, Maryland from Jan. 5 to Mar. 24, 1996 and Dec. 26, 1996 to Feb. 17, 1997.

\begin{tabular}{lcccll}
\hline & \multicolumn{3}{c}{ average } & \multicolumn{2}{c}{ Number of Recaptures } \\
Owls & $n$ & weight & SD & Fall & Winter \\
\hline 1996 & 61 & & & 34 & $14(2 \mathrm{~F}, 2 \mathrm{~T})^{\text {a }}$ \\
Undetermined & 51 & 94.6 & 9.92 & 28 & 11 \\
Female & 9 & 93.4 & 8.23 & 7 & $6(1 \mathrm{~F}, 2 \mathrm{~T})$ \\
Male & 1 & 76.0 & - & - & $1(1 \mathrm{~F})$ \\
\hline 1997 & 5 & & & 3 & $1 \mathrm{~T}$ \\
Female & 3 & 94.0 & 7.21 & 3 & $1 \mathrm{~T}$ \\
Male & 2 & 79.0 & 1.41 & 0 & - \\
\hline Telemetered & 10 & & & 3 & $1 \mathrm{~T}$ \\
Female & 8 & 93.3 & 5.82 & 3 & $1 \mathrm{~T}$ \\
Male & 2 & 79.0 & 1.41 & 0 & - \\
\hline
\end{tabular}

${ }^{\text {a }} \mathrm{F}=$ Foreign Recaptures, $\mathrm{T}=$ Telemetered Recaptures

Table 1-2. T-test results comparing the accuracy of Least Squares (LSE), Maximum Likelihood (MLE) and a robust variation of the Maximum Likelihood (MLE robust) estimators. Mean error values for LSE, MLE and robust MLE were 378.5, 277.9 and $267.0 \mathrm{~m}(\mathrm{n}=50)$ respectively.

\begin{tabular}{llc}
\hline comparison & $\boldsymbol{t}$ & $\boldsymbol{P}$ \\
\hline LSE - MLE & 4.74 & 0.0001 \\
LSE - MLE robust & 5.86 & 0.0001 \\
MLE - MLE robust & 0.66 & 0.514 \\
\hline
\end{tabular}


Table 1-3. Ninety-five percent home range areas (in hectares) using fixed kernel, adaptive kernel, harmonic mean and minimum convex polygon estimators and the number of locations used for the estimate (n). Fixed and adaptive kernel estimates were made using least squares cross validation (LSCV). Owl ID is the owl's radio transmitter frequency in $\mathrm{MHz}$.

\begin{tabular}{lrrrrr}
\hline Owl ID & $\mathrm{n}$ & $\begin{array}{r}\text { Fixed } \\
\text { Kernel }\end{array}$ & $\begin{array}{r}\text { Adaptive } \\
\text { Kernel }\end{array}$ & $\begin{array}{r}\text { Harmonic } \\
\text { Mean }\end{array}$ & $\begin{array}{r}\text { Minimum Convex } \\
\text { Polygon }\end{array}$ \\
\hline 150.178 & 241 & 261.9 & 328.1 & 1152.1 & 333.0 \\
150.217 & 204 & 99.7 & 124.9 & 290.2 & 75.0 \\
150.247 & 167 & 111.8 & 181.1 & 486.7 & 180.8 \\
150.338 & 110 & 64.6 & 100.5 & 235.9 & 68.2 \\
150.417 & 39 & 42.1 & 62.3 & 39.6 & 220.1 \\
150.435 & 74 & 39.7 & 56.6 & 374.9 & 41.9 \\
150.458 & 36 & 240.5 & 300.3 & 214.8 & 136.9 \\
\hline Average & 124 & 122.9 & 164.8 & 399.2 & 150.8 \\
\hline
\end{tabular}

Table 1-4. Ninety-five percent home range areas (in hectares) using fixed and adaptive kernel estimators. Estimates were made using the median bandwidth (148). Harmonic mean home ranges are not included here because they were not set to a standardized grid. A median grid size would have been too small for the larger home ranges. OwI ID is the owl's radio transmitter frequency in $\mathrm{MHz}$.

\begin{tabular}{lrrr}
\hline Owl ID & $\mathrm{n}$ & Fixed Kernel & Adaptive Kernel \\
\hline 150.178 & 241 & 248.6 & 305.5 \\
150.217 & 204 & 95.9 & 121.9 \\
150.247 & 167 & 134.5 & 221.1 \\
150.338 & 110 & 72.6 & 108.5 \\
150.417 & 39 & 38.5 & 56.2 \\
150.435 & 74 & 52.2 & 77.9 \\
150.458 & 36 & 82.1 & 96.4 \\
\hline Average & 124 & 103.5 & 141.1 \\
\hline
\end{tabular}




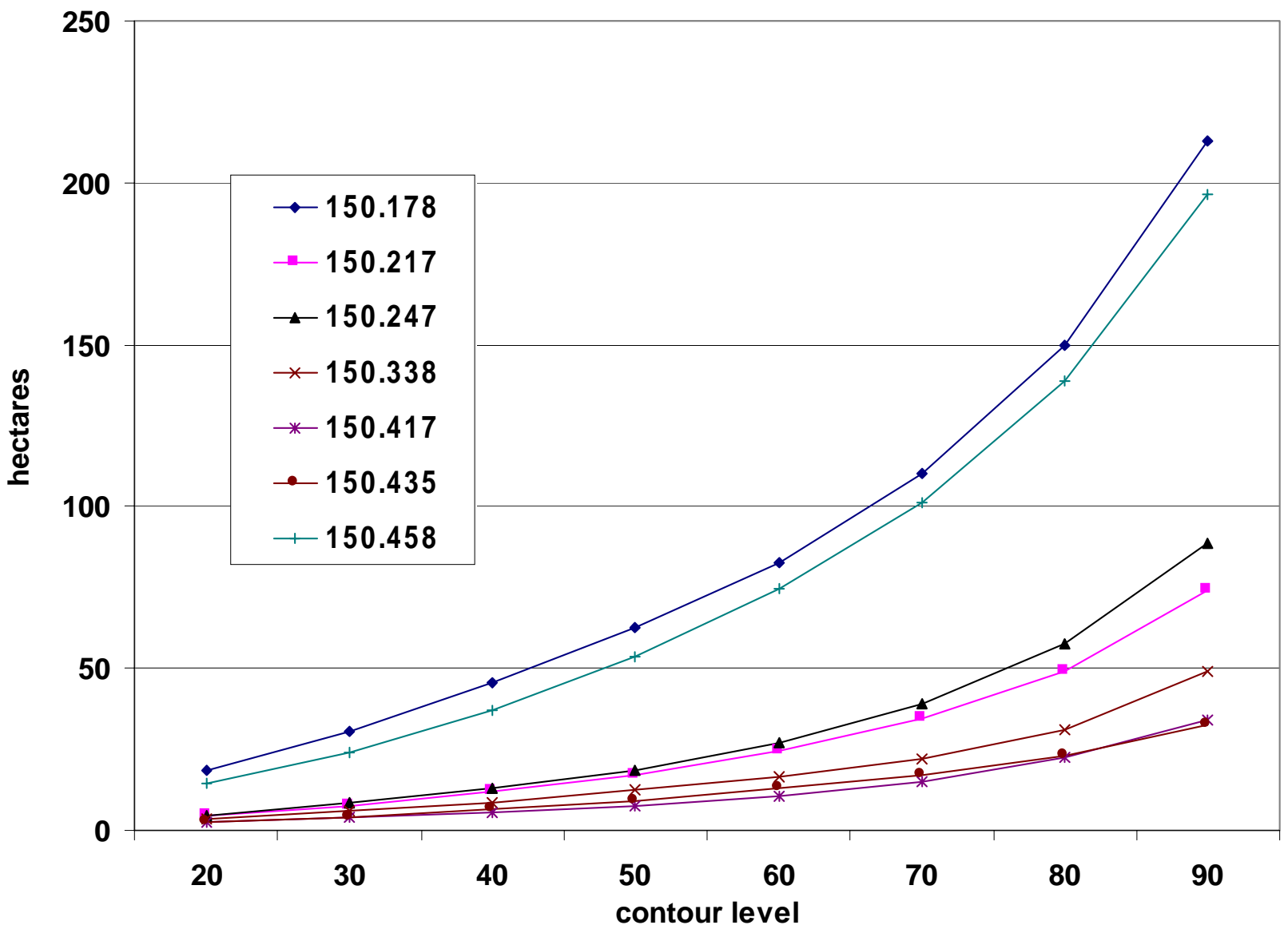

Figure 1-1. Increase in fixed kernel home range area between successive contour levels. Numbers in the legend are owl radio transmitter frequencies in $\mathrm{MHz}$. 


\section{CHAPTER TWO}

\section{WINTER MOVEMENTS, HOME RANGE AND HABITAT USE OF NORTHERN SAW-WHET OWLS AT ASSATEAGUE ISLAND, MARYLAND}

\section{INTRODUCTION}

Little is known about Northern Saw-whet Owl (Aegolius acadicus) wintering habitat and ecology, particularly on coastal barrier islands. Loos and Kerlinger (1993) suggested that coastal shrub habitat may be important to wintering owls. The only published study that I found from a coastal barrier island, involved food habits (Holt et al. 1991). No detailed studies have been conducted in winter anywhere. Only four studies of telemetered Northern Saw-whet Owls exist (Forbes and Warner 1974, Hayward and Garton 1984, Cannings 1987, Cockerel 1997) from any season.

In this study, Northern Saw-whet Owl home ranges were estimated using radiotelemetry. Home ranges and telemetry locations were then used to compare habitat use and availability at Assateague Island, Maryland. Assateague Island is a coastal barrier island known for use by wintering owls from birdwatchers and the Ocean City, Maryland Christmas Bird count (C. Robbins pers. comm. Ocean City, Maryland Christmas Bird Count compiler). Habitat on the island is different in structure and species composition from habitat on the mainland and is an unusual environment for owls that breed in boreal forests. 
The main objectives of the study were to:

1) Determine home ranges of Northern Saw-whet Owls wintering on the Island.

2) Use the sizes and overlap among home ranges and location points in general to determine if owls are staying on the island, using multiple roosts, or exhibiting winter territoriality.

3) Identify habitats that were preferred and avoided by Northern Saw-whet Owls wintering on the island.

\section{STUDY AREA}

The study area was located on Assateague Island, Maryland (a coastal barrier island with an area of 7,252 ha) within the Assateague Island National Seashore (AINS), in Worcester County, Maryland. Thirty-seven km of its 58-km length are in Maryland. The remaining $21 \mathrm{~km}$ are in Accomack County, Virginia. Most of the island is less than two $\mathrm{km}$ wide (Hill 1986).

The study area was 1621.4 ha and consisted of that part of the island from Route 611 south to the Fox Hills. The northern end of the study area is approximately 12 kilometers south of Ocean City, Maryland. Less than half of the length of the study area had paved roads. The island lent itself well to radio telemetry. Relocation of owls was much easier on a long narrow island than would be possible in an unbounded mainland area. In addition, the flat landscape allowed radio signals to travel farther than in rugged terrain and minimized signal bounce.

The climate on the island is moderate. Temperatures during the months of January through March (1992-1996) ranged from -17.8 to 23.9 degrees Celsius. 
Elevations in the coastal plain ecoregion are very close to sea level and elevation on the island is rarely greater than $2 \mathrm{~m}$.

The ocean side of the island is an intertidal dune zone sparsely vegetated with grasses and shrubs (Figure 2-1) including beach plum (Prunus maritimus), beach grass (Ammophila breviligulata) and bayberry (Myrica cerifera). The bay side is an extensive tidal marsh, some of which grades into myrtle swamp (Myrica pensylvanica). Forest habitat on the island consists of mixed loblolly pine (Pinus taeda) and oak forest (Quercus spp.).

I grouped the 25 plant associations from the Assateague Island National Seashore vegetation map into eight habitat types based on vegetation structure (Appendix B). Seven of the habitats occurred in my study area; the most common were tidal marsh and shrubland (Table 2-1). Shrubland includes both myrtle swamp and upland shrubland areas because of their structural similarity.

\section{METHODS}

\section{Owl Capture and Initial Measurements}

Northern Saw-whet Owls were captured in mist nets erected at four locations spaced approximately 3 kilometers apart (Figure 2-1). Each station consisted of two 61 $\mathrm{mm}$ mesh mist nets. The nets were 12 meters long and 2 meters high. The net station at the Hungerford House was arranged two high for a total height of 4 meters. Nets were opened at dusk and closed at dawn one night per week until enough owls were captured for telemetry or efforts proved exhaustive; I attempted to radio-track as many as five owls at any given time. An audiolure was used to attract owls toward the mist 
nets because it has been shown to greatly increase capture probability (Erdman and Brinker 1997, Evans 1997). In 1997, mist net captures were low, so I also attempted to catch owls at roost sites with a capture pole made from a fishing pole and a wire noose. I attempted to locate owls for capture by playing calling tapes at several locations and listening for a response.

Data collected for each captured owl consisted of date, time, net location, mass, wing chord, wing flat, tail length, eye color, bill tip color, and fat condition index. The fat condition index, based on the amount of fat in the furcular depression was scaled as: 0 $=$ no visible fat, $1=33 \%$ full or less, $2=34-66 \%$ full, and $3=$ greater than $66 \%$ full (Rogers 1991). All owls were banded on the leg with United States Fish and Wildlife Service (USFWS) bands. Each owl was aged by molt pattern and molt cards were completed for each adult owl captured.

Sex and age of all birds chosen for telemetry were determined as accurately as possible by wing chord measurements (Weir et al. 1980) and molt (Evans and Rosenfield 1987). Sex was verified from blood analysis of DNA by PE AgGen Inc. ${ }^{1}$ (Fleming et al. 1996) using a small sample of blood (approximately 20 microliters) that was taken when owls were captured. Blood was taken from a wing or leg with the help of a veterinarian. I originally intended to radio-track only juvenile female owls but when capture rates were low in 1997, I attached transmitters to every captured owl. Each owl was fitted with a 3 gram backpack harnessed transmitter representing approximately $3 \%$ of the weight of the bird. The harnesses were constructed from thin elastic bands.

${ }^{1}$ PE AgGen Inc., Davis, California 


\section{Telemetry}

Once owls were released they were found and monitored using a unidirectional roof-mounted antenna from a 4-wheel-drive vehicle. Locations were estimated by triangulation using stations with coordinates known from global positioning systems (GPS) data. Three or more bearings were used for each estimate, using a hand-held receiver and yagi antenna, and locations were made no more than once per hour from sunset to sunrise.

Home ranges were calculated for all owls having 30 or more valid location estimates. Only seven of the 10 individuals that were fitted with transmitters could thus be used to calculate home ranges. Location estimates were overlain against a background map of the island, and any location estimates occurring outside the boundaries of the island were eliminated. Locations with 95\% confidence ellipses with area $>500$ ha were also eliminated because of their limited accuracy.

To account for the influence of roost sites on the size and shape of the home range, I adopted the following rule: if an estimated location was made within an hour before sunrise, the next estimate used for calculating the home range must occur at least one hour after sunset of the following evening. By this time the owl would likely have left the roost and moved to a new location. If an estimate made at dusk was more accurate than one made at dawn of the same day (judging from the confidence ellipse), it was used instead of the earlier estimate. 


\section{Home Range}

The fixed kernel method (Seaman and Powell 1996, Worton 1995) was used to calculate owl home ranges with optimal smoothing parameters chosen by least squares cross validation (LSCV). Kernel methods use a smoothing parameter "h" to smooth contours around location points. Choice of smoothing parameter by LSCV is recommended because of it's objectivity, consistency of estimation, and ability to minimize the difference between true and estimated density of location points (Silverman 1986, Worton 1995, Seaman and Powell 1996). To standardize home ranges across all individuals, resulting smoothing parameters were used to determine a median optimal smoothing parameter. Home ranges were then recalculated with the parameter set to the median value.

I also calculated bi-weekly home ranges for individuals tracked for longer than two weeks to determine if home ranges of individuals with small sample sizes accurately represented a shorter time frame, and if home range size increased over time. The larger data sets were broken down into time frames no shorter than 10 days and no longer than 14 days. The bi-weekly data sets had to include 25 or more location estimates or they were not included. I believe these guidelines resulted in data sets that were very similar to the data used to calculate home ranges for individuals with small sample sizes. Smoothing parameters for bi-weekly home ranges were all calculated by LSCV.

Home range overlap was calculated for each year using all combinations of individuals with overlapping home ranges. Home ranges were re-calculated to include only data from the time frame in which both owls were present. Therefore, overlap was temporal as well as spatial. Area of overlap was calculated by "intersecting" home 
ranges that overlapped in the program ARC/INFO (ESRI Inc.) and tabulating the area of the resulting polygons. Percentage overlap was calculated as two times the area of intersection divided by the total area of both intersecting home ranges. This same formula was used to calculate overlapping Boreal Owl (Aegolius funereus) home ranges (Jacobsen and Sonerud 1987).

\section{Chi Square Analysis}

Geographically contiguous habitats where owls were seldom found and that represented small percentages of available habitat were grouped together (beach with grassland and open water with marsh). The presence of uncommon habitats in the analysis may detract from the results by increasing the number of categories with fewer than five expected observations (Neu et al. 1974).

Habitat at owl location points with 95\% confidence ellipses (an elliptical area with $95 \%$ probability of including the owl) with area of $\leq 1$ hectare was compared with habitat composition of the entire study area using $x^{2}$ analysis. The 1 hectare confidence ellipse area was chosen as a compromise between sample size and accuracy of habitat identification since the probability of correctly identifying habitat increases with location precision. Fifty-four location points representing six of the seven owls that were used for home range analysis met this criterion. The number of points per owl ranged from 1 to 21 . I calculated $95 \%$ confidence intervals for each of five habitats using Bailey's confidence intervals (Cherry 1996). Compositions of available habitat that were higher or lower than the confidence interval for habitat use were considered significantly preferred or avoided at alpha $=0.05$. 


\section{Compositional Analysis}

Compositional analysis offers solutions to some of the problems associated with using radio tracking data to estimate habitat use (Aebischer et al. 1993). Since the $x^{2}$ analysis assumed that each of the 54 location points were independent of the others, this method may not have truly represented the birds' preferred habitats. Studies that use radio locations of different individuals as the sampling unit, such as the $x^{2}$ analysis in this chapter commit an error of pseudoreplication (Hurlbert 1984) because locations of any given individual are not independent. These methods do not account for serial correlation or other types of individual variation. Compositional analysis also allows comparison of different levels of habitat use versus availability. Habitat selection may prove to be more important at one level than another; e.g. comparison of $30 \%$ utilization distribution (habitat use) may not differ significantly from habitat available within 95\% home ranges but may still differ from habitat available in an arbitrarily defined study area.

To analyze owl habitat using compositional analysis, $95 \%$ and $30 \%$ fixed kernel home range contours were overlain on the Assateague Island vegetation map (Figures $2-2-2-8)$. The area of each habitat type within the study area and each of the two contour levels was tabulated using Arcview (ESRI inc.) software (Table 2-1). For analyses, I used the same five categories as used in the $x^{2}$ analysis (with beach and grassland combined and open water combined with marsh).

Habitat proportions were analyzed using the compositional analysis method of Aebischer et al. (1993). I compared habitat use in $30 \%$ with that in $95 \%$ home range areas. Thirty and $95 \%$ areas were also compared with habitat composition within the 
total study area. I used the Wilk's lambda statistic (Chatfield and Collins 1980) to determine which comparisons were significant.

For some owls, habitats were missing from $30 \%$ contours. The $0 \%$ compositions were changed to $0.01 \%$ for the log ratio transformation, a value that was a great deal smaller than the smallest non-zero percentage observed (1.4\%). This allowed the log ratios to be calculated without affecting the other habitat proportions. This $0.01 \%$ change in composition is the same modification made by Aebischer et al. (1993).

A simplified ranking matrix was constructed only for comparisons of proportional habitat use having a significant Wilk's Lambda (at alpha $=0.05$ ). Proportions of habitats used by each individual owl were compared with those available using every possible combination of the formula $\ln \left(\mathrm{X}_{\mathrm{U} 2} / \mathrm{X}_{\mathrm{U} 1}\right)-\ln \left(\mathrm{X}_{\mathrm{A} 2} / \mathrm{X}_{\mathrm{A} 1}\right)$ where $\mathrm{U}_{\mathrm{U} 1}$ and $\mathrm{U}_{2}$ are the compositions of habitat types 1 and 2 that were used by an animal and ${ }_{\mathrm{A} 1}$ and ${ }_{\mathrm{A} 2}$ are the compositions of habitats 1 and 2 that were available. The seven resulting matrices were used to compute the mean and standard deviation of each habitat log ratio and multiple t-tests were performed to determine their differences from zero. Two ratios were computed for each habitat comparison to reveal the full range of the bird's preferences; e.g. proportion of $95 \%$ home range habitat that was pine woods relative to grasslands gave a large positive (preferred) value, while the inverse ratio gave a very small value, indicating that the birds avoided grasslands.

One problem that may result from using home range contours for habitat analysis involves the use of different sample sizes of locational data to calculate home ranges. Aebischer et al. (1993) suggested using the square root of $n$ (number of locations per bird) as a weighting factor to account for differences between individuals in the number of locations used. I did this analysis using the recommended weighting 
factor since the number of locations was so variable among individual owls. The weighting factor is applied to the log ratio of utilized habitat as above (i.e. $\left.\left(n^{-1 / 2}\right)^{\star} \ln \left(X_{\mathrm{U} 2} / X_{U_{1}}\right)\right)$.

I also used the 30 and $95 \%$ habitat compositions to calculate rank preference indices (Johnson 1980, Krebs 1989). This third method is a simple (non-statistical) way to show the relationship between habitat use and availability.

\section{RESULTS}

All owls radio-tracked in 1996 were hatch year (HY) females. In 1997, there were one each second year (SY) and third year (TY) males, one HY female and two after hatch year (AHY) females (Table 2-2). Both male owls slipped out of their transmitter harnesses before data sufficient to estimate home ranges could be collected. Therefore all owls available for use in the home range analysis were females. There were insufficient data to compute a home range for one female owl in 1996; therefore, only seven of the 10 telemetered owls were used in the home range analysis.

For the seven owls used for home range analysis, the number of estimated locations used ranged from 36 to 241 and time tracked ranged from seven to 80 days (Table 2-3). The numbers of estimated locations used and time tracked were lower for the three individuals not used for home range analysis.

The average time required to travel between two consecutive tracking stations and estimate a bearing was four minutes. Since I tried to detect each owl's position from three stations, there were approximately eight minutes between the first and last

measurement for each position. An owl can move from one position to another in eight 
minutes, so this time difference may have affected the accuracy of some location estimates.

Owls appeared to stay on the island, although in 1996 two disappeared after short periods of time leaving no evidence of their fate or location (Table 2-3). The two male owls tracked for less than a week in 1997 were missing for about one week before their transmitters were recovered indicating that they probably had not left the island. While recovering one of the transmitters, an owl was observed roosting above the shed transmitter. Since owls were never seen using roosts used previously by other owls, the roosting owl was probably the male that wore the harness. The bird was not recaptured, so this was not confirmed.

\section{Home Ranges}

The average $95 \%$ fixed kernel home range size was 103.5 ha and home range sizes ranged from 38.5 to 248.6 ha (Table $2-4$ ). The average bi-weekly $95 \%$ home range area was 112.9 ha (Table 2-5). This was somewhat larger than that calculated for owls 150.417 and 150.458 (Table 2-4) indicating that the smaller samples of these two individuals resulted in home ranges that were similar to the bi-weekly home ranges but much smaller than the seasonal home ranges determined for owls with larger sample sizes.

In 1996, only one pair of individuals had overlapping home ranges (Table 2-6) of 65\% (Figure 2-9). In 1997, three pairs overlapped (Table 2-6) and the percentage ranged from $38.2 \%$ to $86.0 \%$ (Figures $2-10,2-11$ and $2-12$ ). The most overlap between any two individuals was between 150.217 and 150.247 (Figure 2-10). The entire range of 150.217 was encompassed by 150.247 and the shapes of the contours were very similar. 


\section{Chi-square}

Habitat use at location points differed from habitat availability $\left(X^{2}=35.9 ; P=\right.$ $0.001 ; \mathrm{df}=4$ ). Pine woods were used more than expected (Table 2-7), while marshopen water habitats were used less than expected. All other habitats were used in proportion to their availability.

\section{Compositional Analysis}

The chi-square distribution of the Wilk's lambda statistic was not significant for any of the three comparisons. The $30 \%$ utilization distribution and $95 \%$ home range area were not significantly different $\left(X^{2}=0.393 ; P=0.983 ; \mathrm{df}=4\right)($ Table 2-1). Similarly, neither the $30 \%$ nor the $95 \%$ usages were significantly different from the availability in the study area $\left(30 \% X^{2}=0.400 ; P=0.983 ; \mathrm{df}=4\right)\left(95 \% X^{2}=0.962 ; P=\right.$ $0.916 ; \mathrm{df}=4)$. When the analysis was done without correcting for differences in sample size, the comparison of $95 \%$ home range use with the study area was significant $\left(x^{2}=\right.$ 11.094, $P=0.026 ; \mathrm{df}=4$ ) so the simplified ranking matrix was constructed for this comparison only (Table 2-8). The ranking matrix was created from the means and $P$ values (students $t$ distribution) of the log ratio differences (Table 2-9).

The ranking of unweighted log ratio differences (Aebischer et al. 1993, Aebischer and Robertson 1992) in the simplified ranking matrix (Table 2-8) showed highest preference for deciduous woods though they were not significantly more preferred than pine woods. The most highly avoided habitat was grassland-beach. No single habitat was significantly avoided or preferred to all other habitats but grassland-beach was significantly avoided when compared with pine woods, deciduous woods and shrubland. 
The average rank differences as described in Krebs (1989) and Johnson (1980) showed the highest preference for pine woods and the highest avoidance of marshopen water within the $30 \%$ home ranges (Table 2-10). Within 95\% home ranges, shrubland was the most preferred while grassland and marsh were both the most highly avoided.

\section{DISCUSSION}

\section{Home Ranges}

In general there is a positive relationship between area and the number of locations used for the home range estimate which reflects the tendency for owls to move from place to place over time. As more data points were collected, owls moved into previously unused areas, thereby increasing their home range sizes.

The areas of the $95 \%$ home ranges were difficult to compare because the sample sizes were so variable. Since bi-weekly home range sizes were similar to those calculated for individuals with small sample sizes (150.417 and 150.458), these individuals probably represent home range for a bi-weekly (or slightly longer) time frame. Home ranges like those calculated for $150.178,150.217,150.247$, and 150.338 with 100 or more points spanning 15 or more days are representative of "winter" home ranges. Home range size appears to increase with time since home ranges of individuals tracked for 15 days or more were larger than bi-weekly home ranges (Tables 2-3 and 2-4). This is supported by my personal observations of daytime roosts in 1997. The fact that owls stayed in an area for weeks at a time before moving to a new location, shows that several weeks may be needed to accurately estimate winter home range. The fact that owls (such as 150.217 and 150.247) sometimes return to areas 
used previously instead of exploring new areas, indicates that home range size becomes stable after some period of time. These observations describe movement patterns of wintering owls at Assateague Island in 1997 and may not apply to Northern Saw-whet Owl populations as a whole.

There was considerable variation in home range size that was not easily explained by sample size differences. For example 150.435 and 150.338 both had larger samples ( $n=74$ and 110 respectively) than $150.458(n=36)$, yet the latter had a much larger home range. This is probably due to individual variation in movements; some individuals simply moved more often or more frequently than others.

Differences in home range size also may be due to differences in quality and availability of habitat. Owls used many of the same areas both years probably because of larger patches of pine in one section of the study area near the Hungerford House (Figure 2-1). Home ranges may be smaller in a large patch of premium habitat because owls would not have to range as far to secure resources such as food and roost trees.

The large degree of home range overlap between individuals shown is not unexpected. Northern Saw-whet Owls are not known to be gregarious or territorial in their wintering areas. If owls are opportunistic hunters they could be expected to move around within areas of suitable habitat in search of prey. Home range overlap in general and especially the overlap of 150.217 and 150.247 and the congruency of the shapes of these two $95 \%$ fixed kernel home ranges indicates that owls may use many of the same areas and are not territorial in these wintering areas. I have found no published work that contradicts this. This congruency also may be due to the configuration of habitat since the $30 \%$ home range was centered in pine woods and because there were patches of pine woods at the periphery of the $95 \%$ contours 
(Figures 2-3 and 2-4). The use of the median optimum bandwidth contributed to the similarity of the shapes and sizes of these two $95 \%$ contours.

It is possible that owls moved in the time period between consecutive bearing estimates, leading to inaccurate location estimates. In some instances this appeared to be true, judging by the resulting bearings. Since owls typically perch and hunt in one place, this probably did not occur very often. Also, inaccurate locations were eliminated so this probably did not affect home range estimates. Nightly location estimates showed that owls tended to stay and hunt in one place, sometimes for several hours or even several nights at a time. If the characterization of the congeneric Boreal Owl as a "sit and wait" predator (Jacobsen and Sonerud 1987) extends to Northern Saw-whet Owls, it would indicate that most location estimates are not subject to this inaccuracy. It is difficult to determine the extent to which owls moved within a nightly home range because of the limited accuracy of these radio-telemetry methods.

Home ranges calculated in this study compare well with other studies (Table 211) excluding those calculated from singing territories (Palmer 1986). However, most studies report breeding season home ranges and the method used to calculate home ranges was typically the minimum convex polygon (MCP) method. I calculated MCP home ranges for the sake of comparison with those studies. The average winter fixed kernel home range for Maryland owls is very close to that reported for the one owl tracked by Forbes and Warner (1974) in Minnesota and smaller than the breeding season ranges of Cannings (1987) in British Columbia. I expected Northern Saw-whet Owl breeding season home range sizes to be constrained by the need to stay close to a nest location, but MCP home ranges calculated by Cannings (1987) were very similar to 
those calculated in this study. The 78 ha MCP home range estimated by Palmer (1986) was a conservative estimate based on "the optimum habitat available".

\section{Habitat Analysis}

The results of habitat analyses were similar among the 3 methods I used, though the $x^{2}$ and compositional analysis did not completely agree. This could be due to differences in the methods or as a result of the analyses being done at different levels. The $x^{2}$ analysis compared the habitat at all location points for all birds with habitats available in the study area, while the compositional analysis compared proportional home range habitat use areas (30\% and $95 \%)$ with each other and with the study area. The home range represents the area used by an individual but may inadvertently include unused areas, some of which may have been avoided habitats. The $x^{2}$ analysis identified pine woods as the most preferred habitat and marsh-open water as the most avoided, which agreed with the Johnson (1980) formulation for rank differences for $30 \%$ home ranges. The rank differences for $95 \%$ area was more consistent with the unweighted log ratio differences in the compositional analysis because both methods identified grassland-beach and marsh-open water as the most avoided habitats. It is clear from these analyses, that forested habitat was preferred and marsh and grassland habitats were avoided.

Both methods of habitat analysis were limited by sample size. The $x^{2}$ analysis may be limited by the number of accurate location points, but the compositional analysis was even more affected by the low number of individual owls since it recognized them as the basic sampling unit. More individuals were probably needed to use the compositional analysis method effectively. The $x^{2}$ analysis used radio location 
points as a sampling unit and was in danger of committing a type one error by pseudoreplication. Further, 54 location points were not a large sample and this may have limited the power of the test.

The imposition of the 1 hectare confidence ellipse for accuracy helps to ensure that habitat is identified correctly, but the sample size was limited as a result. The worst consequence of this imposition is that some combinations of stations used to estimate owl locations may have resulted in more accurate estimates than others because of the arrangement of stations and the angles of bearings taken from them. If this happened routinely, it may have biased the results of the habitat analysis. Several stations contributed few, if any, locations to the analysis. This doesn't necessarily mean that owls were not using the pine woods or avoiding marsh habitat, but it made the results of the $x^{2}$ analysis difficult to interpret.

An assumption of compositional analysis is that habitat use by individuals is independent (Aebischer et al. 1993); i.e. that home ranges may overlap. My home range overlap calculations supported this and Northern Saw-whet Owls are not known to be gregarious or territorial so this assumption is probably valid. The assumption that individual habitat compositions are equally accurate is less likely because the number of locations used for home range calculation was so variable. The fact that the Wilk's lambda statistics were not significant when Aebischer et al. (1993) correction factors for small sample sizes were applied, indicated that an overall sample size of seven may have been too low to detect an effect. Because there were more data on some individuals than others, the preferences of some birds were apparently lost. Home ranges calculated from small samples still reflected important habitat information. 
Winter habitats used by Northern Saw-whet Owls are so variable that comparison between studies is difficult. Coniferous and deciduous habitats both are commonly used. On Assateague Island, deciduous forest habitat was rare and owls were most often found in loblolly pine forest or shrubland (myrtle). Loblolly pine habitat is similar to other coniferous habitats used in winter such as spruce-fir (Simpson 1972), pine groves (Swengel and Swengel 1987), pine plantings and tamarack bog (Mumford and Zusi 1958) and pine plantations (Wilson 1938). Shrubland habitats on Assateague Island may be structurally similar to the more unusual shrub-steppe habitat described as breeding habitat by Marks and Doremus (1988) and Hayward and Garton (1984), or the hawthorne thicket reported as a wintering area by Scott (1938).

Northern Saw-whet Owls at Assateague Island showed a preference for pine and deciduous woodland over marsh-open water, grassland-beach and shrubland habitats in a study area with a limited amount of woodland habitat. The pine habitat provided good cover and presumably a good prey base since these habitats were used during nightly radio-tracking; i.e. they were not used only as diurnal roosts.

This study identified habitats within one coastal barrier island that are important to wintering Northern Saw-whet Owls. The overall importance of barrier island habitat is still unclear. More owls are typically captured at Maryland's inland banding stations than at Assateague Island in autumn and winter regardless of whether captures were high or low during a given year (Brinker et. al. 1997). This probably means that more owls winter in inland than in coastal areas. Whether or not these relative abundances are related to any measure of fitness to individuals remains to be shown. Studies of the differences in quality of inland and coastal habitats could be valuable. 


\section{LITERATURE CITED}

Aebischer, N. J. and P. A. Robertson. 1992. Practical aspects of compositional analysis as applied to pheasant habitat utilization. Pp. 285-293 in Wildlife telemetry: remote monitoring and tracking of animals. (I.G. Priede and S.M. Swift, Eds.). Ellis Horwood, New York, New York.

Aebischer, N. J. P. A. Robertson, and R. E. Kenward. 1993. Compositional analysis of habitat use from animal radio-tracking data. Ecology 74:1313-1325.

Brinker, D. F., K. E. Duffy, D. M. Whalen, B. D. Watts and K. M. Dodge. 1997. Autumn migration of Northern Saw-whet Owls (Aegolius acadicus) in the middle Atlantic and northeastern United States: what observations from 1995 suggest. Pp. 7489 in Biology and conservation of owls of the Northern Hemisphere. (J. R. Duncan, D. A. Johnson, and T. H. Nicholls, Eds.). U. S. Forest Service Gen. Tech. Report NC-190.

Cannings, R. J. 1987. The breeding biology of Northern Saw-whet Owls in southern British Columbia, pp. 193-198 in Biology and conservation of northern forest owls (R.W. Nero, R.J. Clark, R.J. Knapton, and R.H. Hamre, Eds.). U.S. Forest Service Gen. Tech. Report RM-142.

Chatfield, C. and A. J. Collins. 1980. Introduction to multivariate analysis. Chapman and Hall, London.

Cherry, S. 1996. A comparison of confidence interval methods for habitat useavailability studies. J. Wildl. Manage. 60:653-658.

Cockerel, B. E. Jr. 1997. Prey selection of the Northern Saw-whet Owl (Aegolius acadicus) in the southern Appalachian Mountains. M. S. thesis, Appalachian State Univ., Boone, North Carolina.

Erdman, T. H. and D. F. Brinker. 1997. Increasing mist net captures of migrant Northern Saw-whet Owls (Aegolius acadicus) with an audiolure. Pp. 533-544 in Biology and conservation of owls of the Northern Hemisphere. (J. R. Duncan, D. A. Johnson, and T. H. Nicholls, Eds.). U. S. Forest Service Gen. Tech. Report NC-190.

ESRI Inc. 1982 - 1997. ARC/INFO version 7.1.2. Environmental Systems Research Institute Inc. Redlands, California.

ESRI Inc. 1992 - 1997. ArcView GIS Version 3.0a. Environmental Systems Research Institute Inc. Redlands, California.

Evans, D. L. and R. R. Rosenfield. 1987. Remigial molt in fall migrant Long-eared and Northern Saw-whet Owls. Pp. 209-214 in Biology and conservation of northern 
forest owls (R.W. Nero, R.J. Clark, R.J. Knapton, and R.H. Hamre, Eds.). U.S. Forest Service Gen. Tech. Report RM-142.

Evans, D. L. 1997. The influence of broadcast tape-recorded calls on captures of fall migrant Northern Saw-whet Owls (Aegolius acadicus) and Long-eared Owls (Asio otus). Pp. 533-544 in Biology and conservation of owls of the Northern Hemisphere. (J. R. Duncan, D. A. Johnson, and T. H. Nicholls, Eds.). U. S. Forest Service Gen. Tech. Report NC-190.

Forbes, J. E. and D. W. Warner. 1974. Behavior of a radio tagged Saw-whet Owl. Auk 91:783-795.

Fleming, T. L., J. L. Halverson and J. B. Buchanan. 1996. Use of DNA analysis to identify sex of Northern Spotted Owls (Strix occidentalis caurina). Journal of Raptor Research 30:118-122.

Hayward, G. D. and E. O. Garton. 1984. Roost habitat selection by three small forest owls. Wilson Bull. 96:690-692.

Hill, S. R. 1986. An annotated checklist of the vascular flora of Assateague Island (Maryland and Virginia). Castanea 51:265-305.

Holt, D. W., E. Andrews and N. Claflin. 1991. Non-breeding season diet of Northern Saw-whet Owls, Aegolius acadicus on Nantucket Island, Massachusetts. Can. Field Nat. 105:382-385.

Hurlbert, S. H. 1984. Pseudoreplication and the design of ecological field experiments. Ecological Monographs 54:187-211.

Jacobsen, B. V. and G. A. Sonerud. 1987. Home range of Tengmalm's Owl: A comparison between nocturnal hunting and diurnal roosting. Pp. 189-192 in Biology and conservation of northern forest owls (R.W. Nero, R.J. Clark, R.J. Knapton, and R.H. Hamre, Eds.). U.S. Forest Service Gen. Tech. Report RM142.

Johnson, D. H. 1980. The comparison of usage and availability measurements for evaluating resource preference. Ecology 61:65-71.

Krebs, C. J. 1989. Ecological methodology. Harper Collins Publishers, New York, New York.

Loos, G. and P. Kerlinger. 1993. Road mortality of Saw-whet and Screech-Owls on the Cape May peninsula. Journal of Raptor Research 27:210-213.

Marks, J. S. and J. H. Doremus. 1988. Breeding season diet of Northern Saw-whet Owls in southwestern Idaho. Wilson Bull. 100:690-694. 
Mumford, R. E. and R. L. Zusi. 1958. Notes on movements, territory, and habitat of wintering Saw-whet Owls. Wilson Bull. 70:188-191.

Neu, C. W., C. R. Byers and J. M. Peek. 1974. A technique for analysis of utilizationavailability data. J. Wildl. Manage 38:541-545.

Palmer, D. A. 1986. Habitat selection, movements and activity of Boreal and Saw-whet Owls. M.Sc. thesis, Colorado State University, Fort Collins, Colorado.

Rogers, C. M. 1991. An evaluation of the method of estimating body fat in birds by quantifying visible subcutaneous fat. J. Field Ornith. 62:349-356.

Seaman, D. E. and R. A. Powell. 1996. An evaluation of the accuracy of kernel density estimators for home range analysis. Ecology 77:2075-2085.

Scott, T. G. 1938. Some Saw-whet Owls in central lowa. Wilson Bull. 50:239-242.

Silverman, B. W. 1986. Density estimation for statistics and data analysis. Chapman and Hall, London, U.K.

Simpson, M. B. Jr. 1972. The Saw-whet Owl population of North Carolina's Southern Great Balsam Mountains. Chat 36:39-47.

Swengel, S. R. and A. B. Swengel. 1987. Study of a Northern Saw-whet Owl Population in Sauk County Wisconsin. pp. 199-208 in Biology and conservation of northern forest owls (R.W. Nero, R.J. Clark, R.J. Knapton, and R.H. Hamre, Eds.). U.S. For. Serv. Gen. Tech. Rep. RM-142.

Weir, R. D., F. Cooke, M. H. Edwards and R. B. Stewart. 1980. Fall migration of Sawwhet Owls at Prince Edward Point, Ontario. Wilson Bull. 92:475-488.

Wilson, K. A. 1938. Owl studies at Ann Arbor, Michigan. Auk 55: 187-197.

Worton, B. J. 1995. Using Monte Carlo simulation to evaluate kernel-based home range estimators. J. Wildl. Manage. 59:794-800. 
Table 2-1. Habitat composition in the Assateague Island study area, and in $30 \%$ and 95\% Northern Saw-whet Owl fixed kernel home range contours at Assateague Island, Maryland in 1996 and 1997.

\begin{tabular}{lcrccccc}
\hline \multirow{2}{*}{$\begin{array}{l}\text { Habitat } \\
\text { type }\end{array}$} & Study & \multicolumn{3}{c}{$30 \%$ Contour } & \multicolumn{3}{c}{$95 \%$ Contour } \\
\cline { 3 - 9 } & Area & Mean & Min & Max & Mean & Min & Max \\
\hline Loblolly Pine & $6.9 \%$ & $36.0 \%$ & 0 & 88.2 & $12.6 \%$ & 2.0 & 17.9 \\
Deciduous & $1.4 \%$ & $1.4 \%$ & 0 & 32.9 & $2.4 \%$ & 1.2 & 9.2 \\
Upland Grassland & $10.0 \%$ & $2.9 \%$ & 0 & 13.0 & $6.3 \%$ & 2.6 & 15.8 \\
Marsh & $36.1 \%$ & $15.8 \%$ & 0 & 43.8 & $31.1 \%$ & 20.0 & 35.5 \\
Shrubland & $35.7 \%$ & $43.6 \%$ & 6.0 & 52.0 & $45.4 \%$ & 35.5 & 61.0 \\
Beach & $8.6 \%$ & $0.0 \%$ & 0 & 2.9 & $0.8 \%$ & 0.2 & 2.4 \\
Open Water & $1.4 \%$ & $0.4 \%$ & 0 & 0 & $1.4 \%$ & 0 & 2.5 \\
\hline TOTAL & $\mathbf{1 0 0 \%}$ & $\mathbf{1 0 0 \%}$ & & & $\mathbf{1 0 0} \%$ & & \\
\hline
\end{tabular}


Table 2-2. Ages, weights, dates of first capture and winter capture, and net stations telemetered Northern Saw-whet Owls were captured in at Assateague Island, Maryland in 1996 and 1997. Owl ID is the owl's radio transmitter frequency in $\mathrm{MHz}$.

\begin{tabular}{lllllll}
\hline & & & first & radio & winter & winter \\
Owl ID & sex & age & captured & attached & weight $(\mathrm{g})$ & net station \\
\hline 150.178 & F & HY & $11 / 29 / 96$ & $12 / 27 / 96$ & 88 & Hungerford House \\
150.188 & M & SY & $1 / 11 / 97$ & $1 / 11 / 97$ & 80 & G - Road \\
150.217 & F & AHY & $11 / 16 / 96$ & $1 / 8 / 97$ & 102 & A - Road \\
150.247 & F & AHY & $10 / 31 / 96$ & $1 / 11 / 97$ & 92 & Hungerford House \\
150.268 & M & TY & $1 / 11 / 97$ & $1 / 11 / 97$ & 78 & G - Road \\
150.318 & F & HY & $10 / 22 / 95$ & $1 / 14 / 96$ & 100 & A - Road \\
150.338 & F & HY & $10 / 30 / 95$ & $2 / 5 / 96$ & 94 & Hungerford House \\
150.417 & F & HY & $11 / 12 / 95$ & $1 / 14 / 96$ & 93 & A - Road \\
150.435 & F & HY & $11 / 23 / 95$ & $1 / 5 / 96$ & 84 & Hungerford House \\
150.458 & F & HY & $11 / 25 / 95$ & $1 / 5 / 96$ & 93 & G - Road \\
\hline
\end{tabular}


Table 2-3. Number of days spent tracking, dates tracked, number of locations estimated and number used for home range calculations after eliminating inaccurate locations of Northern Saw-whet Owls at Assateague Island, Maryland in 1996 and 1997. Owl ID is the owl's radio transmitter frequency in $\mathrm{MHz}$.

\begin{tabular}{lclrr}
\hline Owl ID & $\begin{array}{l}\text { Number of } \\
\text { days tracked }\end{array}$ & $\begin{array}{l}\text { dates } \\
\text { tracked }\end{array}$ & Points & $\begin{array}{l}\text { Points } \\
\text { used }\end{array}$ \\
\hline 150.178 & 53 & estimated & \\
$150.188^{\text {a }}$ & 6 & Jan 12 to Jan 18, 1997 & 18 & 0 \\
150.217 & 80 & Jan 8 to Mar 28, 1997 & 241 & 204 \\
150.247 & 50 & Jan 12 to Mar 2, 1997 & 193 & 167 \\
$150.268^{\text {a }}$ & 5 & Jan 12 to Jan 17, 1997 & 17 & 0 \\
$150.318^{\text {a }}$ & 4 & Jan 21 to Jan 25, 1996 & 15 & 0 \\
150.338 & 15 & Feb 11 to Feb 26, 1996 & 143 & 110 \\
150.417 & 15 & Jan 15 to Jan 30, 1996 & 49 & 39 \\
150.435 & 26 & Jan 6 to Feb 1, 1996 & 79 & 74 \\
150.458 & 7 & Jan 13 to Jan 20,1996 & 40 & 36 \\
\hline
\end{tabular}

a Home ranges were not calculated for these individuals. 
Table 2-4. Ninety-five percent fixed kernel home range areas (in hectares). Estimates were made using the median bandwidth $(148 \mathrm{~m})$. Owl ID is the owl's radio transmitter frequency in $\mathrm{MHz}$.

\begin{tabular}{lrr}
\hline Owl ID & $\mathrm{n}$ & 95\% home range \\
\hline 150.178 & 241 & 248.6 \\
150.217 & 204 & 95.9 \\
150.247 & 167 & 134.5 \\
150.338 & 110 & 72.6 \\
150.417 & 39 & 38.5 \\
150.435 & 74 & 52.2 \\
150.458 & 36 & 82.1 \\
\hline Average & 124 & 103.5 \\
\hline
\end{tabular}


Table 2-5. Bi-weekly (per 2 weeks) Northern Saw-whet Owl 95\% fixed kernel home ranges in hectares. ID is the owl's radio transmitter frequency in $\mathrm{kHz}$ (above $150 \mathrm{MHz}$ ).

\begin{tabular}{|c|c|c|c|c|}
\hline $\begin{array}{l}\text { ID and } \\
\text { bi-week }\end{array}$ & $\begin{array}{c}\text { \# of } \\
\text { locations }\end{array}$ & $\begin{array}{c}\text { days } \\
\text { tracked }\end{array}$ & $\begin{array}{l}\text { dates } \\
\text { tracked }\end{array}$ & $\begin{array}{l}95 \% \text { area } \\
\text { fixed kernel }\end{array}$ \\
\hline 178 bi-week 1 & 86 & 13 & $12 / 28 / 96-01 / 10 / 97$ & 190.2 \\
\hline 178 bi-week 2 & 33 & 13 & $01 / 12 / 97-01 / 25 / 97$ & 179.6 \\
\hline 178 bi-week 3 & 34 & 14 & $01 / 27 / 97-02 / 10 / 97$ & 54.1 \\
\hline 178 bi-week 4 & 30 & 16 & $02 / 11 / 97-02 / 27 / 97$ & 98.2 \\
\hline 178 bi-week 5 & 29 & 13 & 02/28/97 - 03/10/97 & 225.0 \\
\hline 178 bi-week 6 & 29 & 10 & $03 / 11 / 97-03 / 21 / 97$ & 98.3 \\
\hline 217 bi-week 1 & 40 & 11 & $01 / 08 / 97-01 / 19 / 97$ & 33.2 \\
\hline 217 bi-week 2 & 40 & 11 & $01 / 20 / 97-02 / 02 / 97$ & 188.9 \\
\hline 217 bi-week 3 & 40 & 14 & 02/03/97 - 02/17/97 & 28.6 \\
\hline 217 bi-week 5 & 33 & 11 & 03/02/97 - 03/13/97 & 98.7 \\
\hline 217 bi-week 6 & 25 & 12 & 03/15/97 - 03/27/97 & 53.1 \\
\hline 247 bi-week 1 & 51 & 10 & $01 / 12 / 97-01 / 22 / 97$ & 44.0 \\
\hline 247 bi-week 2 & 44 & 11 & $01 / 23 / 97-02 / 03 / 97$ & 151.4 \\
\hline 247 bi-week 3 & 35 & 13 & $02 / 04 / 97-02 / 17 / 97$ & 63.4 \\
\hline 247 bi-week 4 & 33 & 11 & 02/18/97 - 03/01/97 & 325.9 \\
\hline 338 bi-week 1 & 88 & 10 & $02 / 11 / 96-02 / 21 / 96$ & 55.7 \\
\hline 435 bi-week 1 & 30 & 10 & $01 / 11 / 96-01 / 21 / 96$ & 30.8 \\
\hline MEAN & 41 & 12 & & 112.9 \\
\hline
\end{tabular}


Table 2-6. Fixed kernel home range overlap of Northern Saw-whet Owls at Assateague Island, Maryland in 1996 and 1997. Owl ID is the owl's radio transmitter frequency in $\mathrm{MHz}$.

\begin{tabular}{cccc}
\hline \multicolumn{3}{c}{ Area of overlap } \\
Dates & Owl IDs & in hectares & Percent overlap \\
\hline Jan. 13 - Jan 20, 1996 & $150.458-150.435$ & 37.66 & $65.0 \%$ \\
Jan. 12 - Mar. 2, 1997 & $150.217-150.247$ & 91.23 & $86.0 \%$ \\
Jan. 8 - Mar. 21, 1997 & $150.178-150.217$ & 63.42 & $41.7 \%$ \\
Jan. 12 - Mar. 2, 1997 & $150.178-150.247$ & 57.47 & $38.2 \%$ \\
\hline
\end{tabular}


Table 2-7. Habitat composition and 95\% confidence intervals for habitat use (from 54 location points) and expected composition of Northern Saw-whet Owls at Assateague Island, Maryland in 1996 and 1997.

\begin{tabular}{lccc}
\hline Habitat Type & $\begin{array}{c}\text { Habitat } \\
\text { Used }\end{array}$ & $\begin{array}{c}\text { Habitat } \\
\text { Available }\end{array}$ & $\begin{array}{c}\text { Confidence } \\
\text { Intervals }\end{array}$ \\
\hline Loblolly Pine & $52 \%$ & $7 \%$ & $0.330-0.686$ \\
Deciduous & $4 \%$ & $1 \%$ & $0.0001-0.153$ \\
Grassland / Beach & $0 \%$ & $19 \%$ & $-1.0-1.0$ \\
Marsh / Open Water & $11 \%$ & $37 \%$ & $0.024-0.257$ \\
Shrubland & $33 \%$ & $36 \%$ & $0.172-0.509$ \\
\hline
\end{tabular}


Table 2-8. Simplified ranking matrix (following Aebischer et al. 1993) for habitat preferences of Northern Saw-whet Owls radio-tracked at Assateague Island, Maryland in 1996 and 1997. The matrix was constructed from the comparison of 95\% home range with habitat available in the study area without the use of the Aebischer et al. (1993) correction factor for small sample sizes. Each mean element in the matrix was replaced by its sign; a triple sign represents significant deviation from random at $P<$ 0.05 (students $t$ distribution). Rank is from most avoided to most preferred (determined from the number of positive values in each row). Denominator habitats are in columns, while numerators are in rows.

\begin{tabular}{lcccccc}
\hline & Pine & Decid. & Grass & Marsh & Shrub & Rank \\
\hline Pine & & - & +++ & + & + & 3 \\
Decid. & + & & +++ & +++ & + & 4 \\
Grass & --- & --- & & - & -- & 0 \\
Marsh & - & --- & + & & --- & 1 \\
Shrub & - & - & +++ & +++ & & 2 \\
\hline
\end{tabular}


Table 2-9. Mean log ratio differences (for all owls) used to construct the simplified ranking matrix (Table 2-10) and $t$ distributions from habitat used by Northern Saw-whet Owls at Assateague Island, Maryland in 1996 and 1997. Inverted ratios produced the 10 negative values in the simplified matrix.

\begin{tabular}{ccccr}
\hline Ratio & Mean & SD & $t$ & $P$ \\
\hline Pine/Grass & 1.472 & 0.952 & 4.090 & 0.006 \\
Pine/Marsh & 0.735 & 0.860 & 2.260 & 0.065 \\
Pine/Shrub & 0.249 & 0.935 & 0.704 & 0.508 \\
Decid./Pine & 0.173 & 0.768 & 0.594 & 0.574 \\
Decid./Grass & 1.645 & 0.672 & 6.473 & 0.001 \\
Decid./Marsh & 0.908 & 0.874 & 2.749 & 0.033 \\
Decid./Shrub & 0.421 & 0.778 & 1.432 & 0.202 \\
Marsh/Grass & 0.737 & 0.911 & 2.141 & 0.076 \\
Shrub/Grass & 1.223 & 0.734 & 4.411 & 0.005 \\
Shrub/Marsh & 0.486 & 0.274 & 4.690 & 0.003 \\
\hline
\end{tabular}

Table 2-10. Average rank differences between habitat types (Johnson 1980) used by Northern Saw-whet Owls at Assateague Island, Maryland in 1996 and 1997. Negative numbers were preferred and positive numbers were avoided habitats.

\begin{tabular}{lrr}
\hline Habitat & $30 \%$ & $95 \%$ \\
\hline Pine Woods & -1.786 & -0.571 \\
Deciduous Woods & -0.929 & -0.429 \\
Upland Grassland & 0.714 & 1 \\
Marsh & 2.714 & 1 \\
Shrubland & -0.714 & -1 \\
\hline
\end{tabular}


Table 2-11. Comparison of Northern Saw-whet Owl home range sizes from Assateague Island, Maryland in 1996 and 1997 with results of other studies.

\begin{tabular}{|c|c|c|c|c|}
\hline Location & $\mathrm{n}$ & Method & Home Range (ha) & Author \\
\hline Minnesota & 1 & $\begin{array}{l}\text { Minimum Convex } \\
\text { Polygon }\end{array}$ & 113.6 & $\begin{array}{l}\text { Forbes and } \\
\text { Warner (1974) }\end{array}$ \\
\hline Colorado & 15 & $\begin{array}{l}\text { estimated from size of } \\
\text { singing territory }\end{array}$ & 78 & Palmer (1986) \\
\hline $\begin{array}{l}\text { British } \\
\text { Columbia }\end{array}$ & 2 & $\begin{array}{l}\text { Minimum Convex } \\
\text { Polygon }\end{array}$ & 150.5 & $\begin{array}{l}\text { Cannings } \\
(1987)\end{array}$ \\
\hline Maryland & 7 & $\begin{array}{l}\text { Minimum Convex } \\
\text { Polygon }\end{array}$ & 150.8 & This Study \\
\hline Maryland & 7 & Fixed Kernel (LSCV) ${ }^{a}$ & 122.9 & This Study \\
\hline
\end{tabular}

a Least Squares Cross Validation 


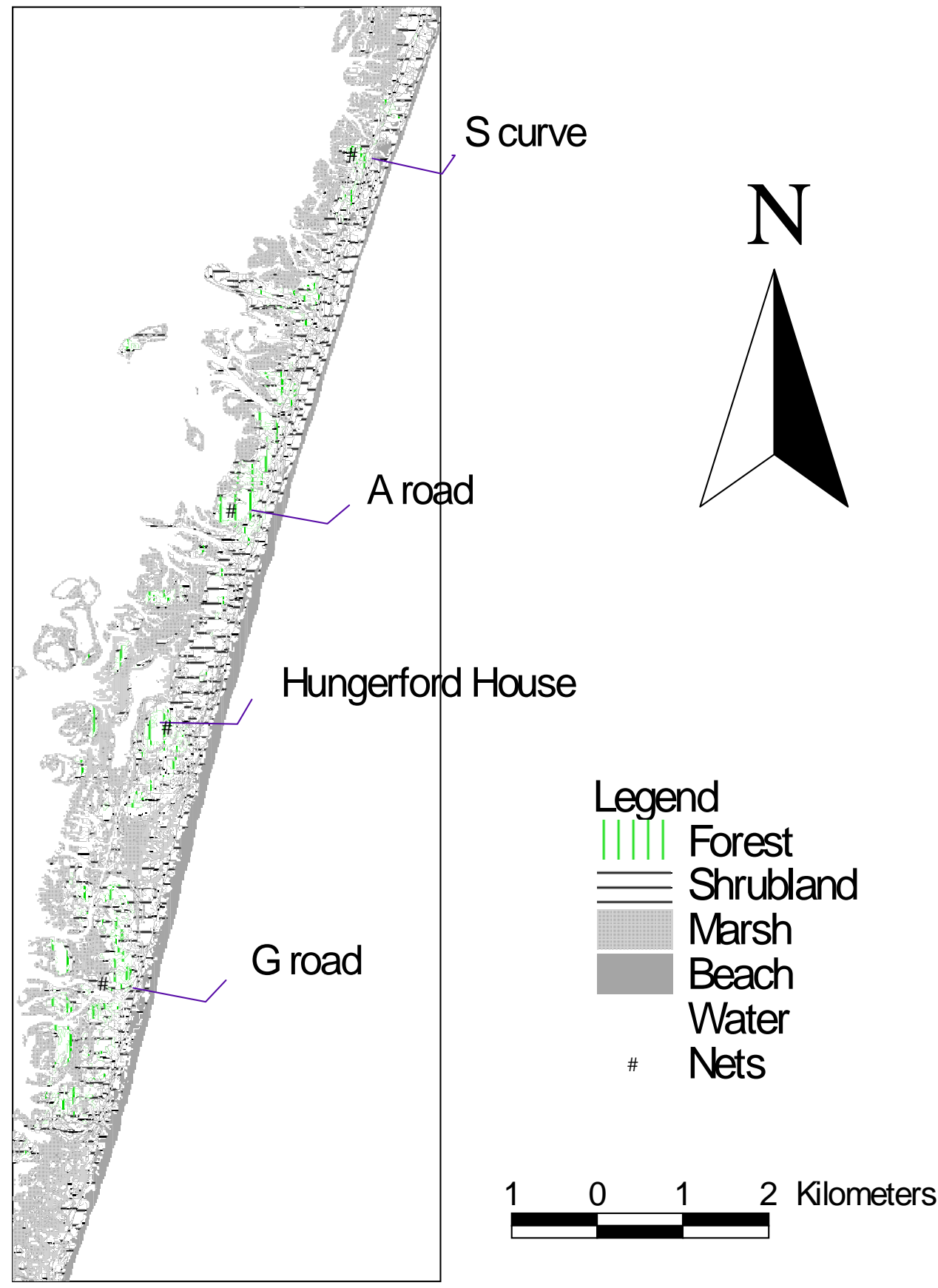

Figure 2-1. The Assateague Island, Maryland study area and net stations used to capture Northern Saw-whet Owls in 1996 and 1997. 


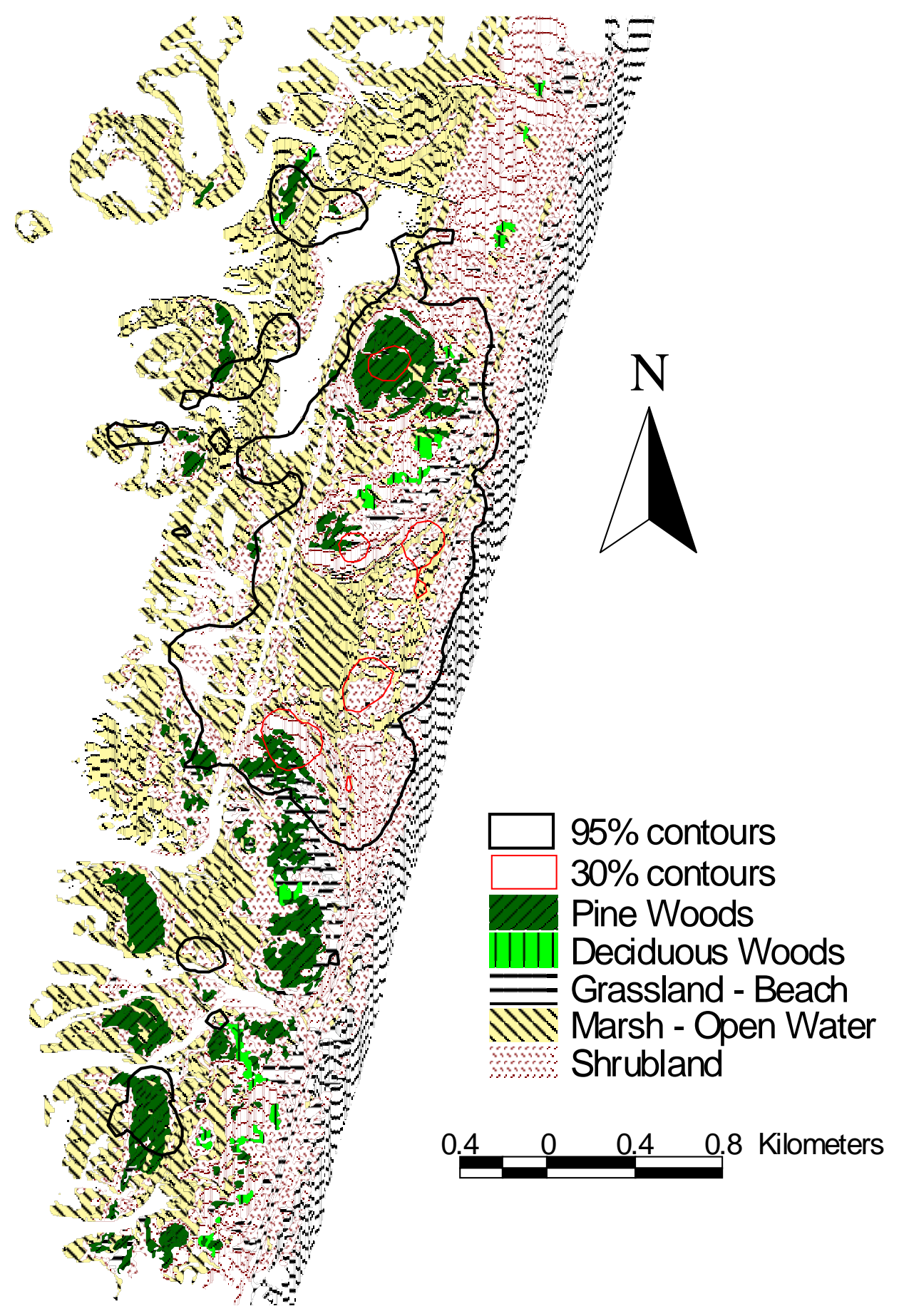

Figure 2-2. Thirty and 95\% fixed kernel home ranges (using a set bandwidth of $148 \mathrm{~m}$ ) and habitat use of owl 150.178 at Assateague Island, Maryland in 1997. 


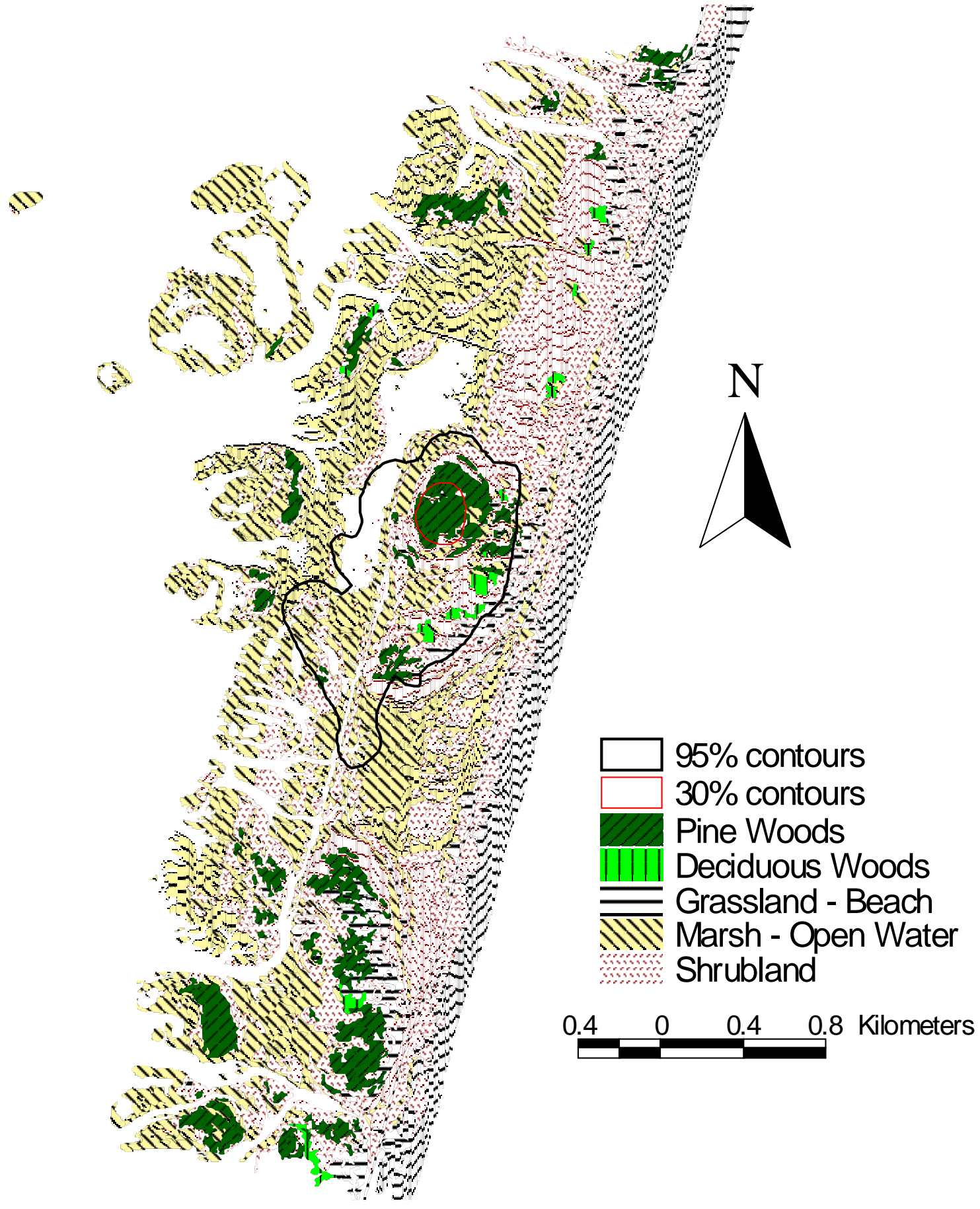

Figure 2-3. Thirty and 95\% fixed kernel home ranges (using a set bandwidth of $148 \mathrm{~m}$ ) and habitat use of owl 150.217 at Assateague Island, Maryland in 1997. 


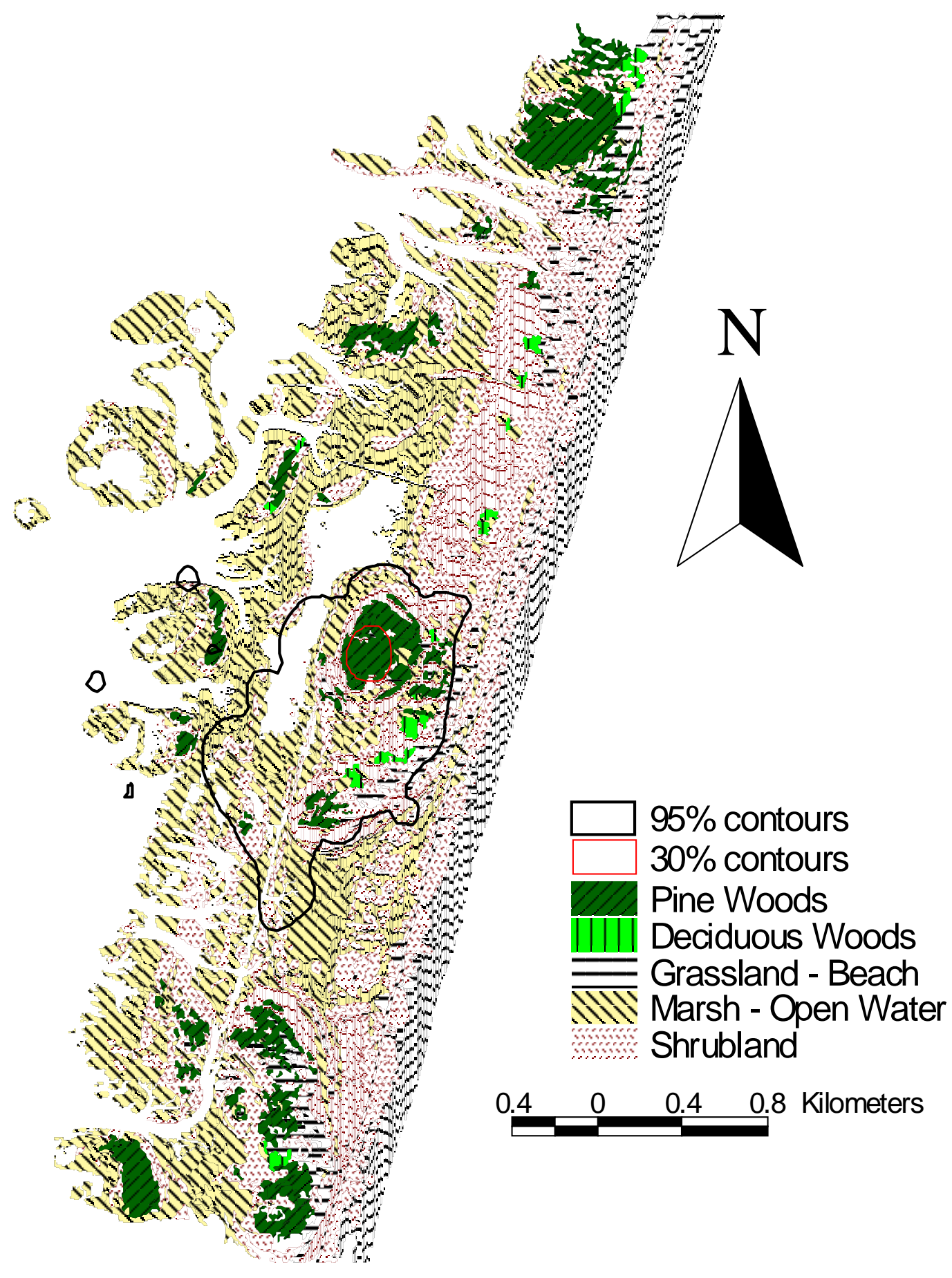

Figure 2-4. Thirty and $95 \%$ fixed kernel home ranges (using a set bandwidth of $148 \mathrm{~m}$ ) and habitat use of owl 150.247 at Assateague Island, Maryland in 1997. 


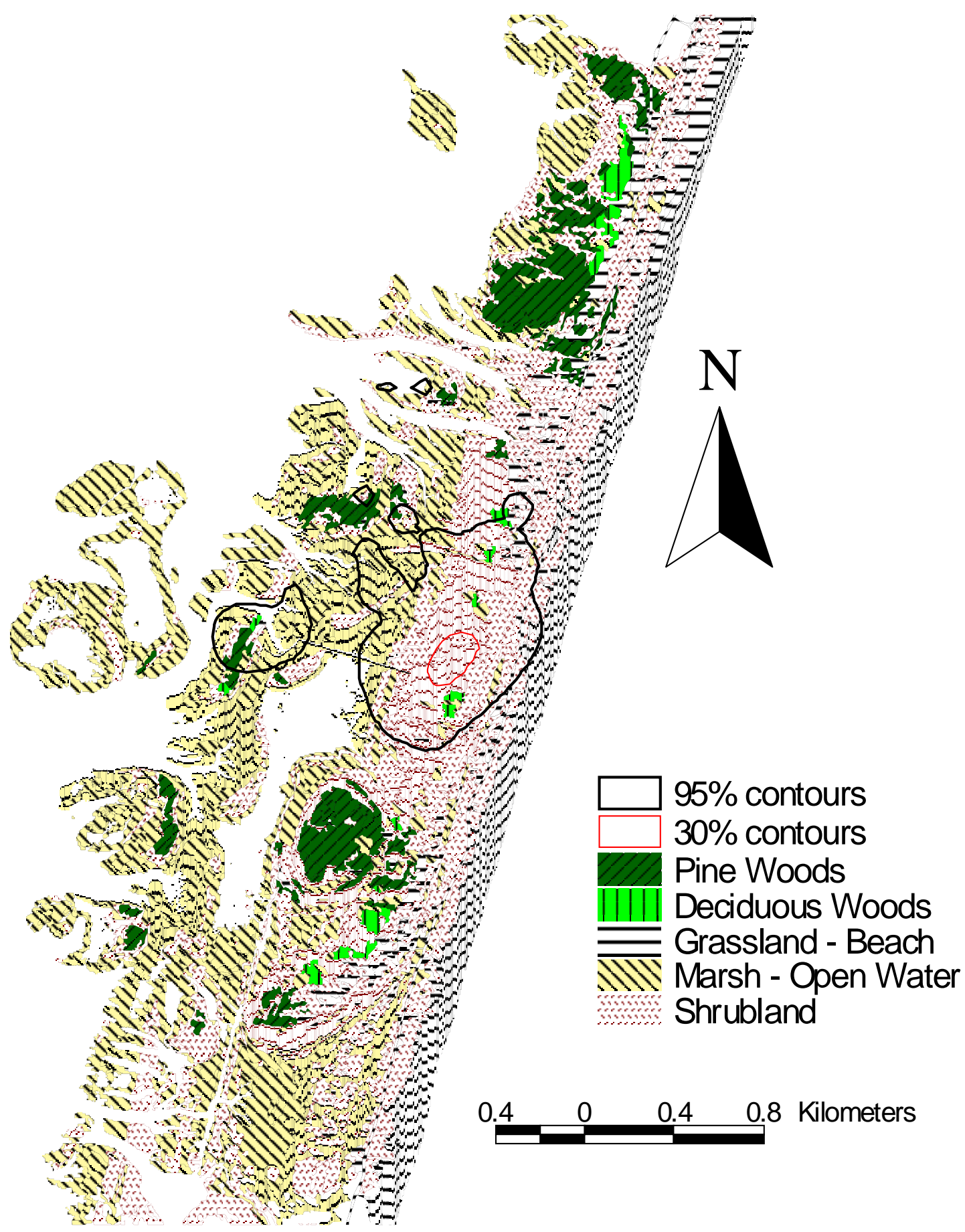

Figure 2-5. Thirty and 95\% fixed kernel home ranges (using a set bandwidth of $148 \mathrm{~m}$ ) and habitat use of owl 150.338 at Assateague Island, Maryland in 1996. 


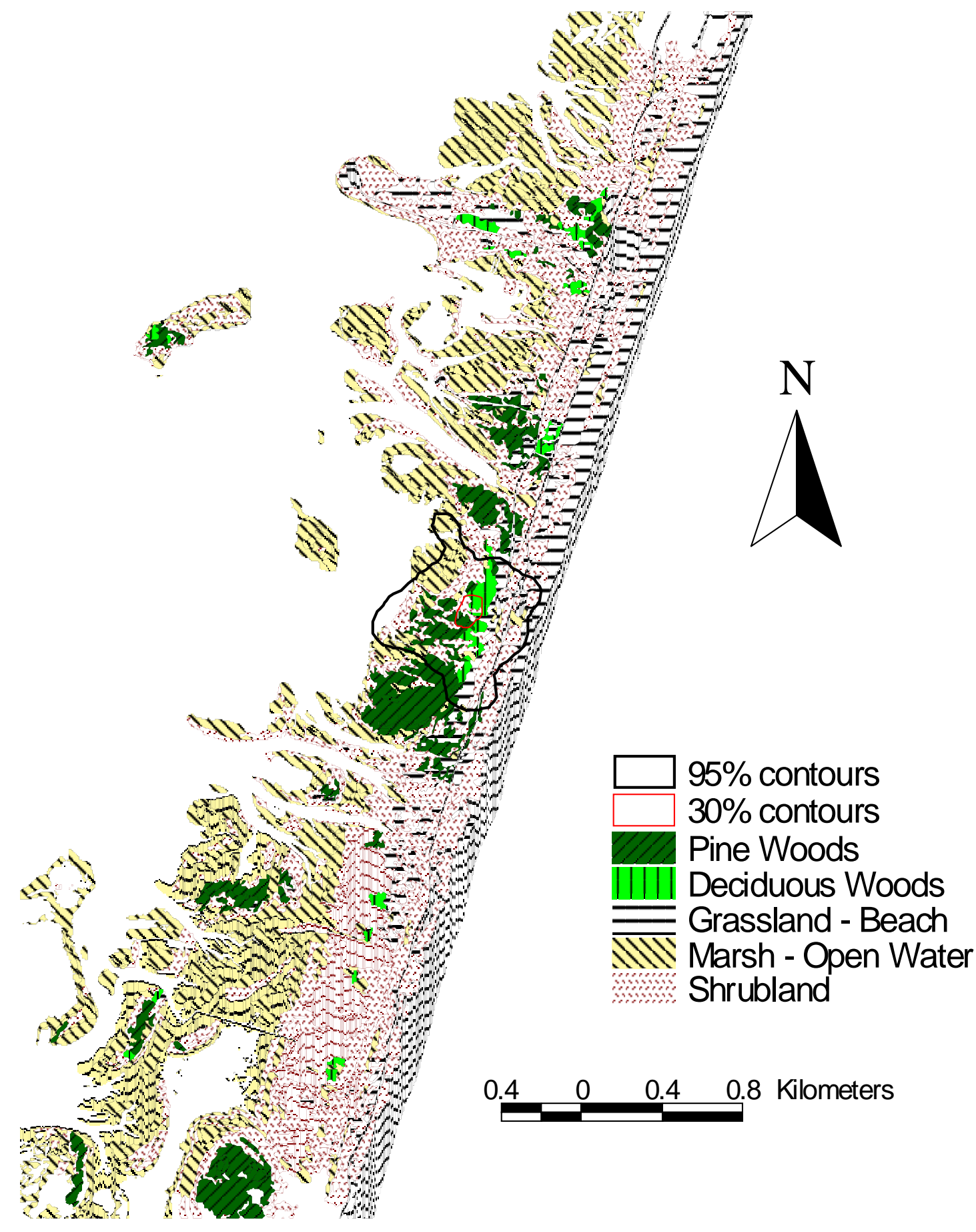

Figure 2-6. Thirty and 95\% fixed kernel home ranges (using a set bandwidth of $148 \mathrm{~m}$ ) and habitat use of owl 150.417 at Assateague Island, Maryland in 1996. 


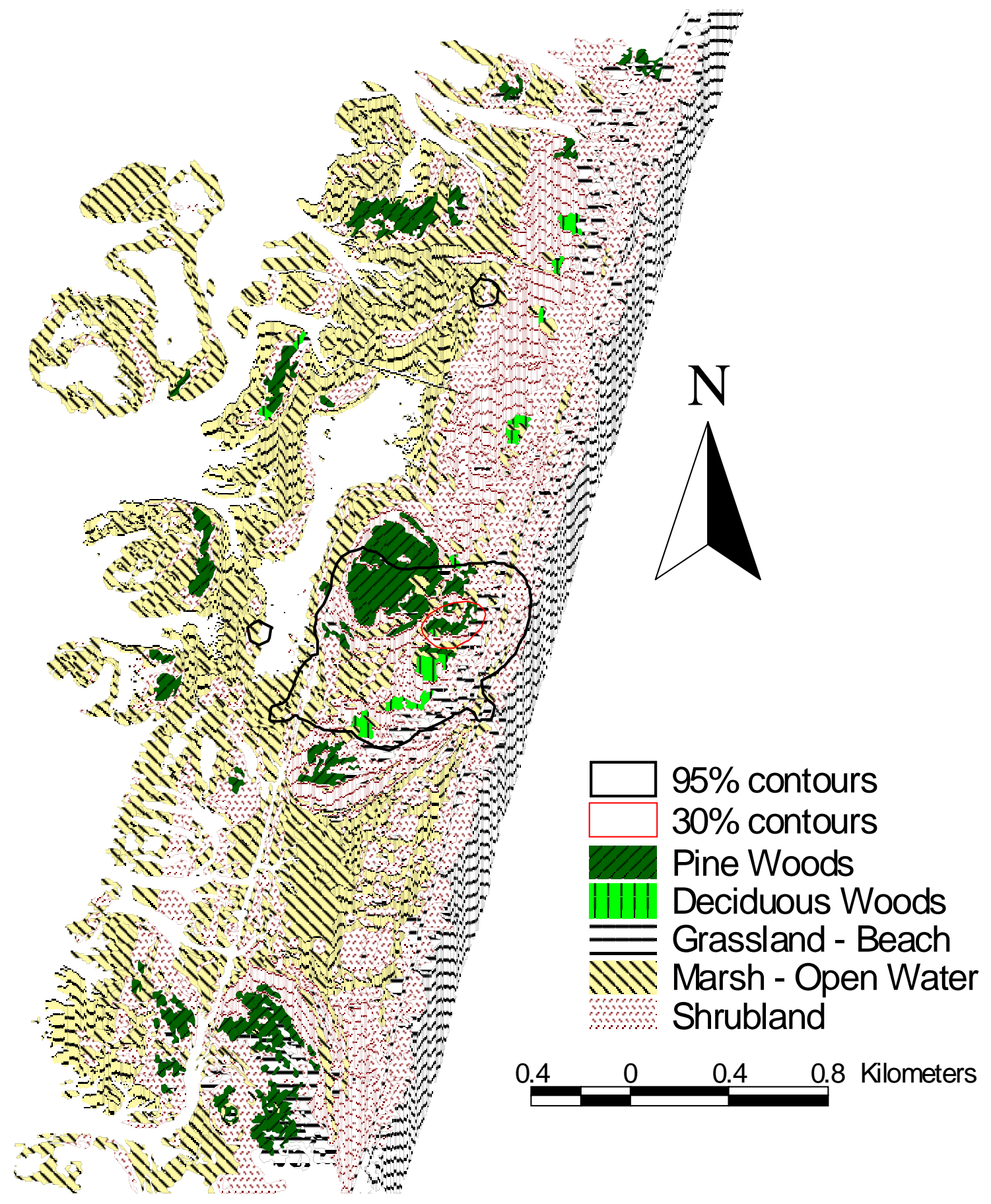

Figure 2-7. Thirty and 95\% fixed kernel home ranges (using a set bandwidth of $148 \mathrm{~m}$ ) and habitat use of owl 150.435 at Assateague Island, Maryland in 1996. 


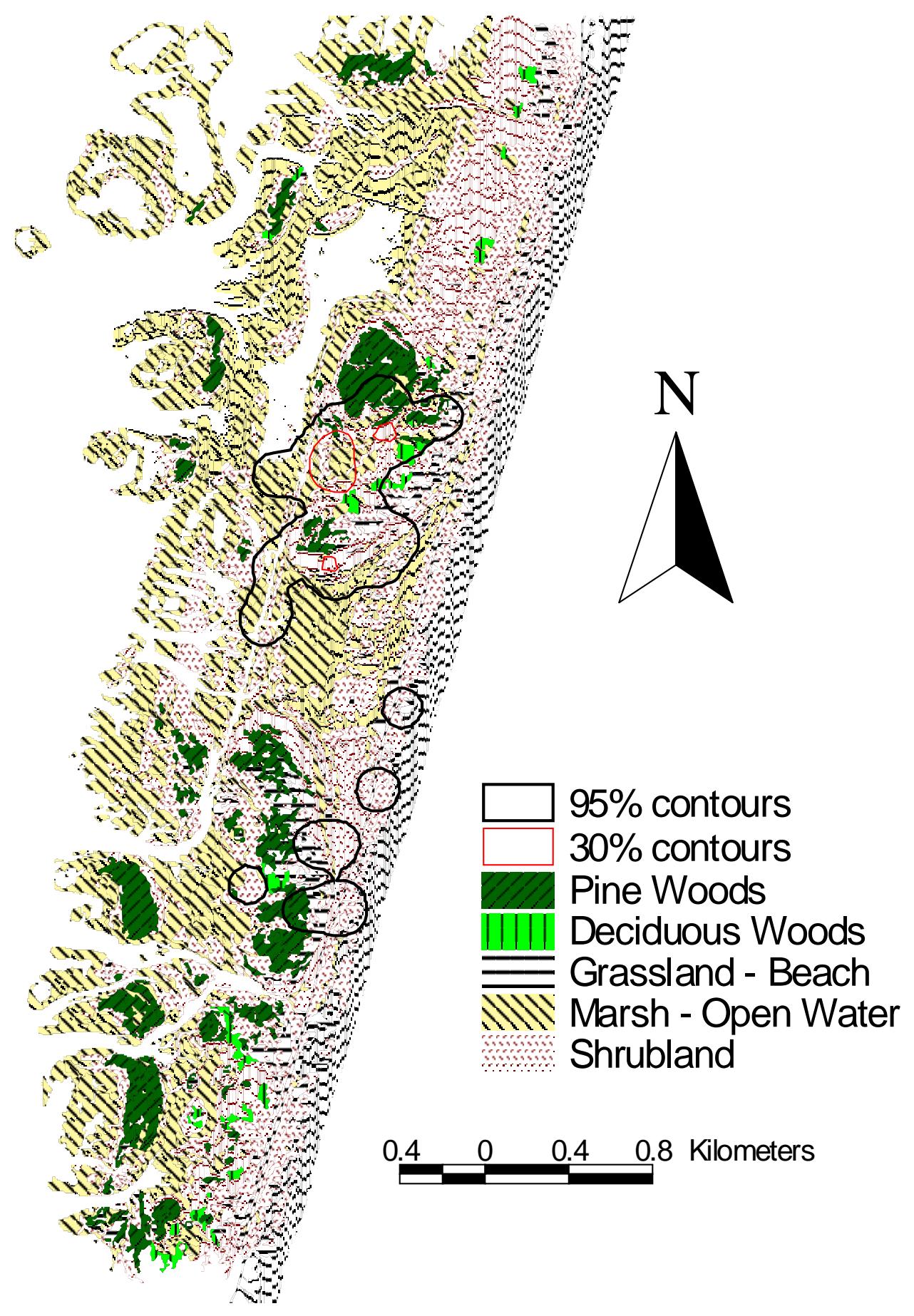

Figure 2-8. Thirty and 95\% fixed kernel home ranges (using a set bandwidth of $148 \mathrm{~m}$ ) and habitat use of owl 150.458 at Assateague Island, Maryland in 1996. 

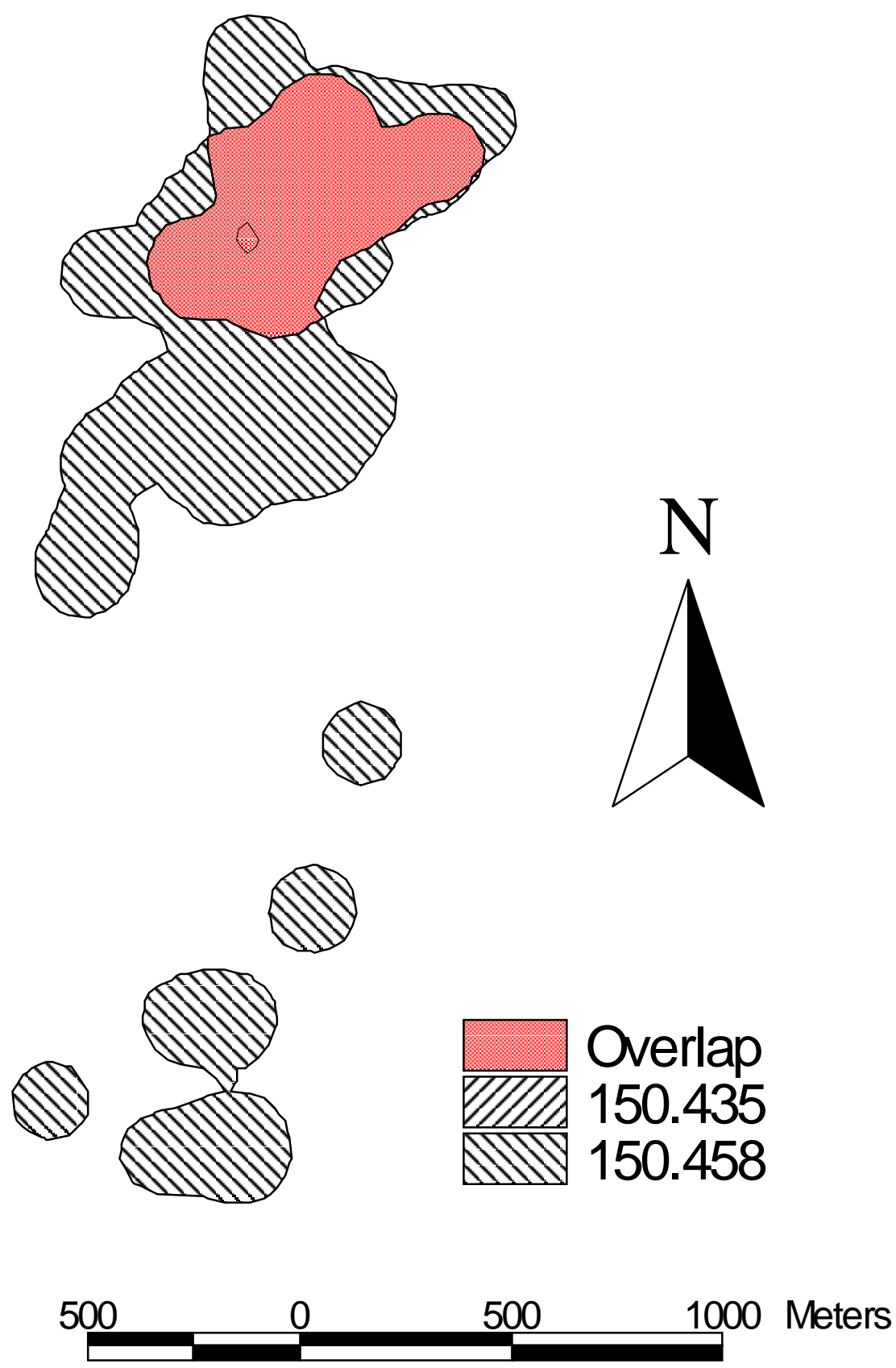

Figure 2-9. Area of $95 \%$ home range overlap between owls 150.435 and 150.458 at Assategue Island, Maryland from Jan. 13 to Jan. 20, 1996. 

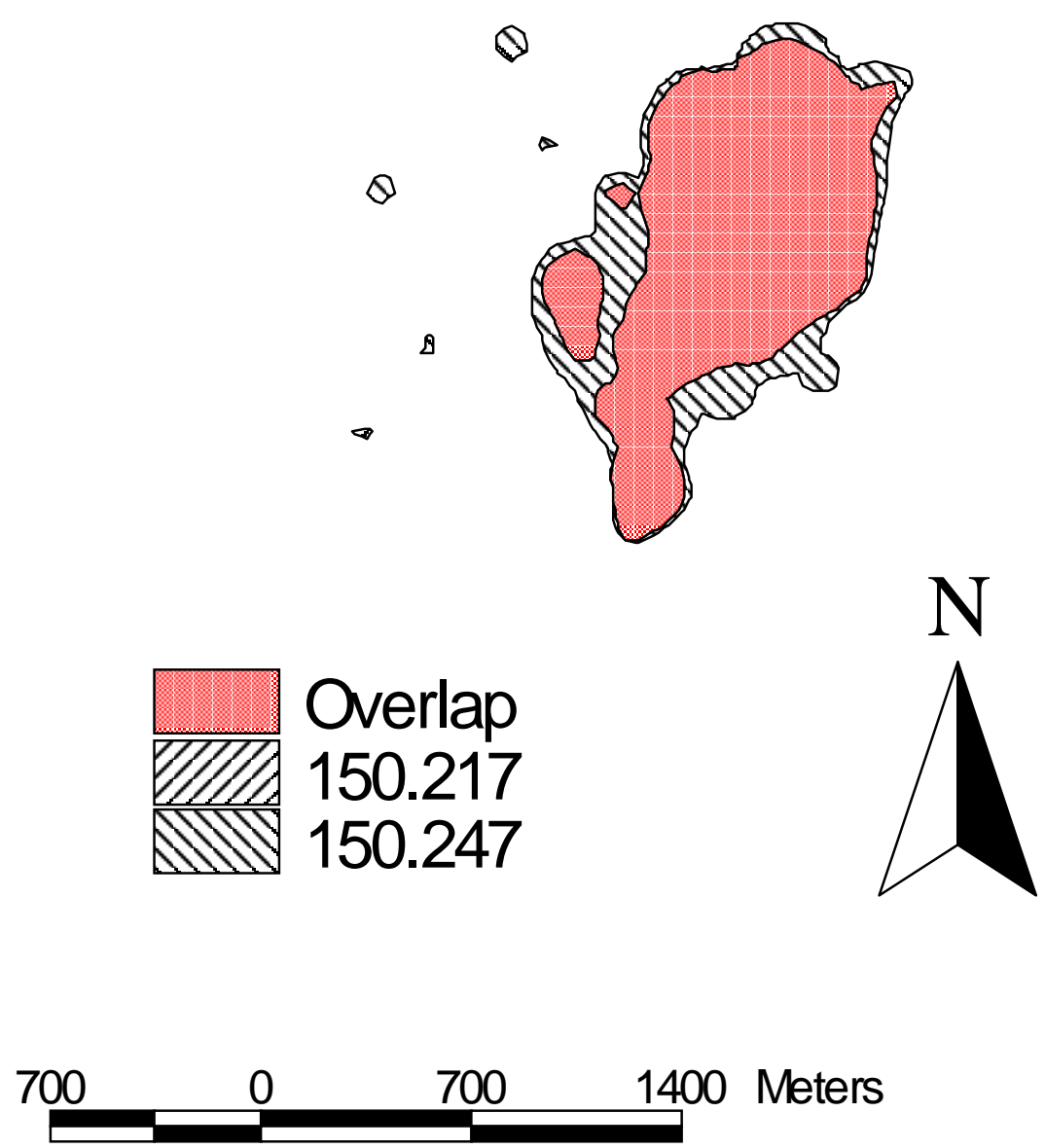

Figure 2-10. Area of 95\% home range overlap between owls 150.217 and 150.247 at Assateague Island, Maryland from Jan. 12 to Mar. 2, 1997. 


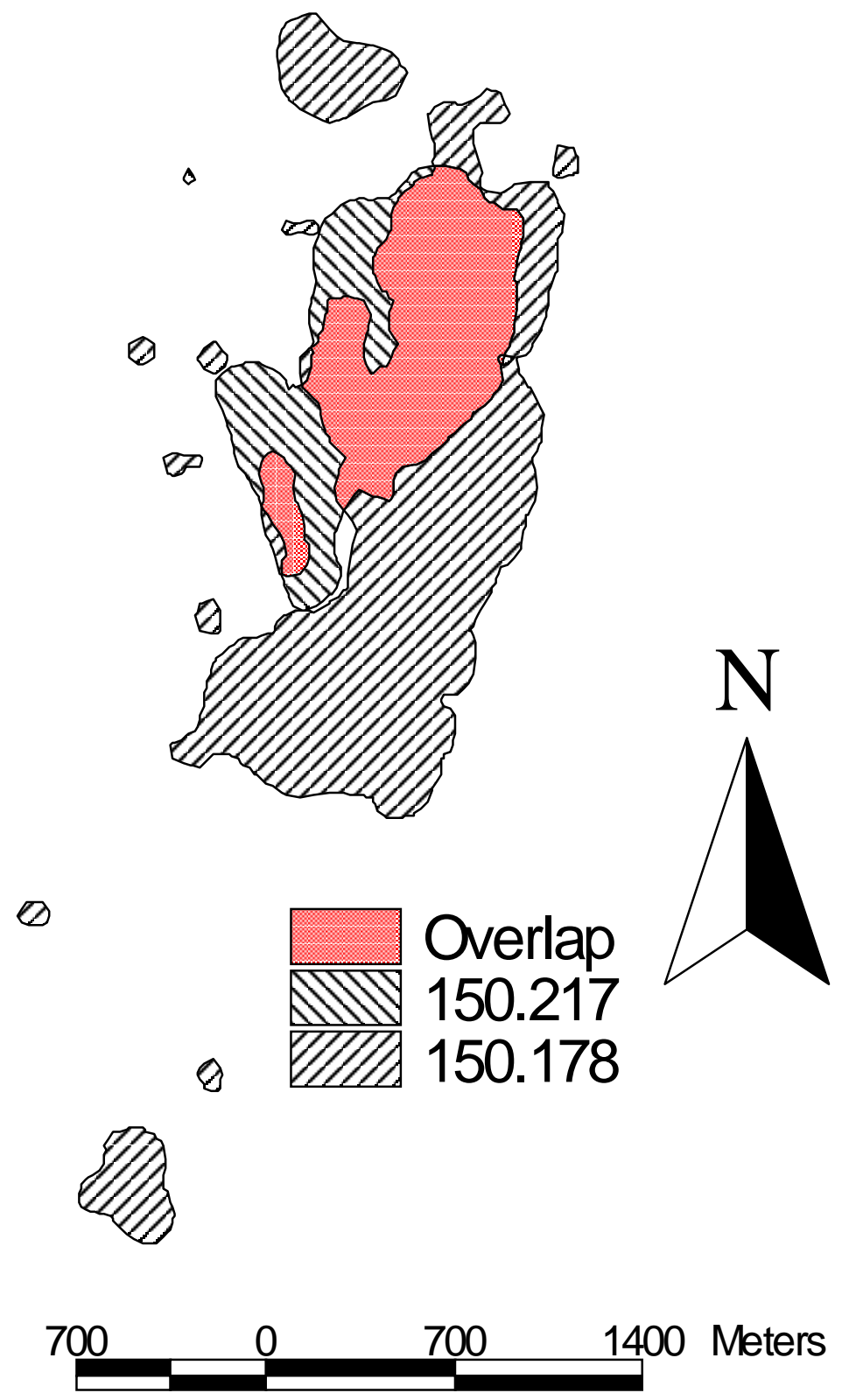

Figure 2-11. Area of $95 \%$ home range overlap between owls 150.178 and 150.217 at Assateague Island, Maryland from Jan. 8 to Mar. 21, 1997. 

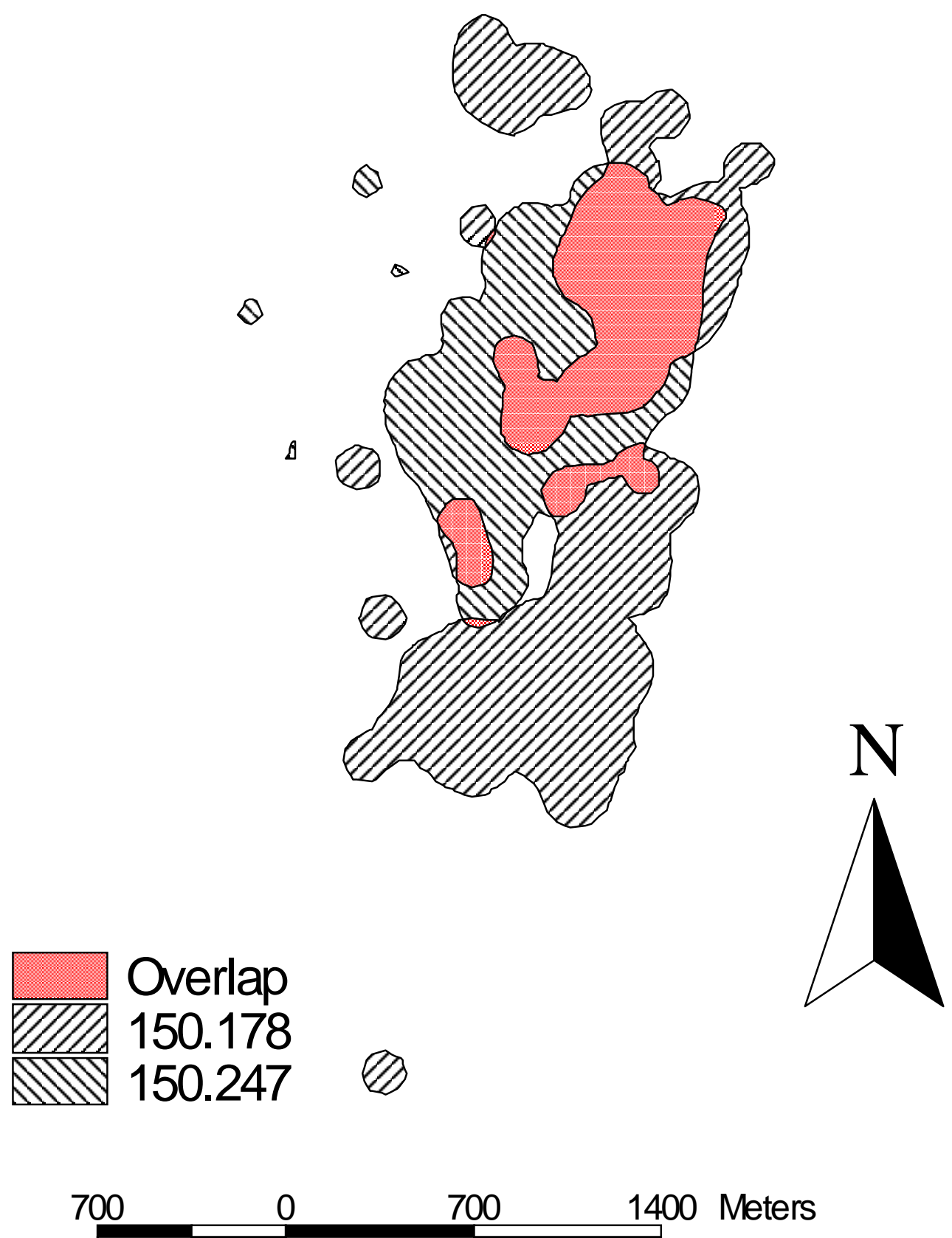

Figure 2-12. Area of $95 \%$ home range overlap between owls 150.178 and 150.247 at Assateague Island, Maryland from Jan. 12 to Mar. 2, 1997. 


\section{CHAPTER THREE}

\section{DIURNAL ROOST SITE CHARACTERISTICS OF NORTHERN SAW-WHET OWLS WINTERING AT ASSATEAGUE ISLAND, MARYLAND}

\section{INTRODUCTION}

Several studies of Northern Saw-whet Owl (Aegolius acadicus) biology have examined diurnal roost site characteristics in different North American regions (Randle and Austing 1952, Hayward and Garton 1984, Grove 1985, Swengel and Swengel 1987, Swengel and Swengel 1992). No information is available for roost site characteristics of Northern Saw-whet Owls wintering on a coastal barrier island. The coastal shrub community is a unique environment that may provide important habitat for wintering Northern Saw-whet Owls (Loos and Kerlinger 1993). The island flora includes many plant species that are missing from inland habitats and the structure of vegetation is very different from that of most inland habitats in the eastern United States.

Knowledge of diurnal roost site characteristics important to Northern Saw-whet Owls leads to a better understanding of their habitat requirements. A study that identifies important roost-site characteristics can help determine whether or not an area can support owls. Identification of the roost-site characteristics that are important to owls may help generate hypotheses as to why those characteristics are important. The uniqueness of this habitat and the relative lack of information from these areas makes this study of wintering Northern Saw-whet Owl ecology very important. The primary 
objective of the study was to identify characteristics of diurnal roost sites important to Northern Saw-whet Owls wintering at Assateague Island, Maryland.

\section{STUDY AREA AND METHODS}

Assateague Island is a narrow coastal barrier island of approximately 7,252 ha located just south of Ocean City, Maryland in Worcester County Maryland and Accomack County, Virginia (Hill 1986). The study area, located within Assateague Island National Seashore, included 1,621 ha. It consisted of tidal marsh (36.1\%), shrubland (35.7\%), loblolly pine forest (Pinus taeda) (6.9\%), and deciduous forest $(1.4 \%)$, with some grassland $(10.0 \%)$ and beach $(8.6 \%)$ on the eastern side of the island. Open water makes up the remaining 1.4\% (Appendix B). Roosting habitat occurs primarily in the shrubland and forested areas with few suitable perches in other habitats.

I identified 29 Northern Saw-whet Owl day-roost sites used by four individual owls on Assateague Island in 1997 and one site (one owl) in 1996. Roosts were located by radio-tracking owls fitted with three gram backpack transmitters, and flagged so that they could be re-located and their characteristics measured after owls had left. I measured vegetation and roost site characteristics on a $3 \mathrm{~m}$ radius circular plot (Figure 3-1) centered on the roost tree. The following variables were measured: number of stems $<2.5 \mathrm{~cm} \mathrm{DBH}$, number of stems $2.5 \mathrm{~cm}-8.0 \mathrm{~cm} \mathrm{DBH}$, roost tree height, percent canopy cover, average canopy height, average shrub height, roost tree $\mathrm{DBH}$, distance to nearest tree, and percent ground cover (Appendix C). Each roost site was compared with a random site $30 \mathrm{~m}$ away in similar habitat. This site was chosen by spinning a compass 15 times and using the resulting bearing to determine its direction from the 
roost tree. Additional variables measured at roost sites that did not apply to random sites were roost height, distance perched from trunk, and orientation of the roost branch (Appendix D).

I used stepwise logistic regression (Hosmer and Lemeshow 1989) (entry level = 0.15 ; stay level $=0.10$ ) to compare habitat characteristics of roost and random sites. The initial model included 12 variables: tree height, canopy cover, average canopy height, average shrub height, roost tree $\mathrm{DBH}$, number of stems $<2.5 \mathrm{~cm}$, number of stems $>2.5 \mathrm{~cm}$, distance to nearest tree and four categories of ground cover (shrub, leaves, sticks and other). If no trees occurred within $6 \mathrm{~m}$ of the roost tree, a default value of $7 \mathrm{~m}$ was used for distance to the nearest tree. I also used Wilcoxon rank sums to test for differences between roosts used by owls in loblolly pine and myrtle with respect to the same 12 variables listed above. The non-parametric test was used because of small sample sizes.

I used dates and location information from the same 30 roost sites to describe owl movement patterns through time. Roosts were the centers of activity and the areas of activity shifted occasionally. Visits were not made with any regularity due to time constraints. Priority was given to owls that were easy to locate, and to those that had obviously moved to a new location.

\section{RESULTS}

Roost sites usually were located in either pine woods or wet woodlands. Nineteen of 29 roosts were in loblolly pine (Pinus taeda) (Table 3-1). Three of the five birds roosted primarily in pine woods, while a fourth individual moved regularly between pine woods and wax myrtle (Myrica cerifera) swamp areas. Of the nine roosts in myrtle, 
eight were used by the same individual. One roost was in a multiflora rose (Rosa multiflora), one was in a red maple (Acer rubrum) and another was in a red cedar (Juniperus virginiana).

Average roost height for all five owls was $2.9 \mathrm{~m}$ while the height of the roost tree averaged $6.1 \mathrm{~m}$ (Table 3-2). Average roost orientation was to the southeast of the tree, at 170 degrees. Owls perched an average of $116 \mathrm{~cm}$ from the trunk. Percent cover around the roost averaged $50 \%$ above and $24 \%$ below the roost.

Roosts often occurred in dense vegetation. Number of stems $<2.5 \mathrm{~cm}$ averaged 183.2 at roost sites (Table 3-2) and 58.3 at random sites (Table 3-3). Habitat variables at one roost site in a red cedar (Juniperus virginiana) was not measured because of thick greenbriar (Smilax spp.) and other stems close to the roost tree. Many roosts were difficult to locate because of extensive cover provided by the surrounding vegetation.

Logistic regression identified five variables that differed between roost sites and random sites. Roost sites (Table 3-2) had more stems $>2.5 \mathrm{~cm} \mathrm{DBH}\left(\chi^{2}=6.63, P=\right.$ $0.01, \mathrm{df}=29)$ and more stems $<2.5 \mathrm{~cm} \mathrm{DBH}\left(\chi^{2}=4.09, P=0.04, \mathrm{df}=29\right)$ than random plots (Table 3-3; Figure 3-2). Tree diameters were significantly higher at roost sites $\left(X^{2}=4.69, P=0.03, \mathrm{df}=29\right)$ and the distance to nearest tree was significantly lower at roost sites $\left(X^{2}=5.97, P=0.02, \mathrm{df}=29\right.$; Figure $\left.3-3\right)$. Average canopy height was significantly lower at roost sites $\left(X^{2}=6.42, P=0.01, \mathrm{df}=29\right)$ than at random sites. No ground cover variables were significantly different between roost and random sites at alpha $=0.05$ (Figure 3-4)

The Wilcoxon rank sums test showed significant differences between loblolly pine and myrtle roost sites for most variables (Table 3-4). Loblolly pines were taller 
than myrtles $(Z=-3.20, P=0.001, \mathrm{df}=8)$, and birds roosted higher in the pines than in myrtle $(Z=-3.59, P=0.0003, \mathrm{df}=8)$. Canopy cover and average canopy height were greater at loblolly pine roosts $(Z=-3.69, P=0.0002, \mathrm{df}=8)$ and $(Z=-3.03, P=0.003$, $\mathrm{df}=8)$. Average shrub height was lower $(Z=3.25, P=0.001, \mathrm{df}=8)$ at loblolly pine roosts. Loblolly pine roost tree DBH's were significantly larger $(Z=-3.60, P=0.0003$, df $=8$ ) than myrtle roosts. Distance to nearest tree was significantly shorter at loblolly pine roosts $(Z=3.40, P=0.0006, \mathrm{df}=8)$ since anything smaller than $8.0 \mathrm{~cm} \mathrm{DBH}$ was not considered a tree (Appendix C). Number of stems $<2.5 \mathrm{~cm} \mathrm{DBH}$ was higher at myrtle roosts $(Z=2.12, P=0.034, \mathrm{df}=8)$. Two ground cover percentages were significantly different. Sticks made up higher percentages of plots that surrounded loblolly pine roosts $(Z=-2.11, P=0.035, \mathrm{df}=8)$ and the category "other" was more common at myrtle roosts than at pine roosts $(Z=1.97, P=0.049$, df $=8)$. The "other" category consisted of mostly grass (65\%) and water (close to $35 \%$ ). There were no significant differences between loblolly pine and myrtle roosts in above or below cover.

\section{Movements Between Roosts}

Owl 150.217 roosted in a section of pine woods for over two weeks before moving approximately $668 \mathrm{~m}$ to a sparsely wooded area of younger pines and wax myrtle where she roosted in a young pine for about three weeks. She then returned to the original pine woods and roosted in a different pine about five meters away from the original roost tree. Three days later she was back in the sparsely wooded area in the same young pine tree used previously.

Owl 150.178 was never found at the same roost twice. This owl moved around several times and had the largest home range of the seven owls. Owl 150.247 did not 
appear to use the same roost trees but did remain relatively faithful to two separate areas of pine woods. The patterns of this owl were similar to those of 150.217 moving from one area to another and back again. Other roosts were visited only once, so movements were not applicable.

\section{DISCUSSION}

It appears that Northern Saw-whet Owls on Assateague Island, chose roost sites that provided good cover, often far from the trunk (Table 3-5). This distal positioning on the branch is appropriate for a small lightweight owl, whereas a larger, heavier bird would probably be too conspicuous or too heavy for such a perch. Grove (1985) described Northern Saw-whet Owl roosts as being far from the main trunk "where cover density was greatest". Not all the roosts in this study had large perch distances but this was often true. Occasionally owls were observed sitting close to the trunk.

Average roost height from this study was lower than that found by Hayward and Garton (1984) but similar to that found by Randle and Austing (1952). Roost height in this study and that of Randle and Austing (1952) may be influenced by shrubland and younger loblolly pine roosts that were typically shorter. Many of the loblolly pine roosts were higher up in trees with foliation beginning above $3 \mathrm{~m}$ but roosts in younger pines were much lower. These roosts probably caused the mean roost height to be low. Average roost height in Randle and Austing's (1952) study could have been similarly influenced by two roosts (of 15) occurring in Japanese honeysuckle (Lonicera japonica). The range of roost heights at Assateague Island was slightly greater than the range of heights from other studies. Average roost height (perch height) using only loblolly pine roost sites was similar to that in Idaho (Hayward and Garton 1984). Average height at 
myrtle roosts was lower than for other studies, probably as the result of the lower height of the myrtles.

Of the four other Northern Saw-whet Owl roost site studies, only Hayward and Garton (1984) measured roost tree height and roost tree diameter at breast height $(\mathrm{DBH})$. They found higher tree heights and larger DBH's in Idaho than I found at Assateague Island, Maryland. The smaller tree sizes at Assateague Island may be the result of stunted growth caused by the harsh coastal environment, or may simply be due to differences between the loblolly pines at Assateague Island and the ponderosa pine (Pinus ponderosa), lodgepole pine (Pinus contorta) and douglass fir (Pseudotsuga menziesii) in Idaho.

Owl selection for roosts with a greater number of stems could be due to the extra cover provided by greater nearby stem densities. Roost sites with the highest stem densities often were wax myrtles in marsh areas where the stems were predominantly common reeds (Phragmites australis) which are often $>2 \mathrm{~m}$ tall. Other roost sites in loblolly pine (Pinus taeda) woods had high surrounding densities of greenbriar (Smilax spp.). Judging by the difficulty of finding some of these roosts from the ground, both of these plant species provided excellent cover from predators.

Cover above the roost averaged twice as high as below which could indicate that protection from aerial predators is more important to the roosting owls than cover from below. I expected to find significantly more cover below the roost at myrtle sites since they are closer to the ground and more susceptible to terrestrial predators but cover above and below the roost did not differ between pine and myrtle roosts. Thus, owls possibly were keying in on cover in roost selection. 
Differences in roost heights and tree diameters between loblolly pine and myrtle roosts are characteristic of those tree species. There was generally little or no canopy cover at myrtle roosts. Average canopy height was low, consisting almost entirely of the shrub layer. Distance to the nearest tree was shortest at loblolly pine sites because trees less than $8.0 \mathrm{~cm}$ DBH were not considered to be trees, and shrubs close to myrtle roosts usually had smaller DBHs. The higher number of stems $<2.5 \mathrm{~cm} \mathrm{DBH}$ at myrtle roosts was primarily the result of dense common reed (phragmites spp) at those sites.

Only one bird routinely roosted in myrtle; three were typically in pine and the remaining owl was represented by a single myrtle roost in 1996. I expected to find owls in pines since conifers are well known roost trees for Northern Saw-whet Owls and owls in general. The behavior of the one owl that roosted in myrtles exemplifies the uniqueness of the coastal barrier island as Northern Saw-whet Owl habitat. Considering the small sample of telemetered owls in this study, it is uncertain how common the myrtle roost-sites are. At least one other bird roosted in myrtle in 1996. Owl 150.338 was observed in a myrtle roost once and its $95 \%$ home range was mostly shrubland ( $30 \%$ utilization distribution was entirely shrubland). Most owls chose to roost in pines even though pine woods habitat was limited in the study area (i.e. it was less common than shrubland). Radio telemetry was essential to locating myrtle roosts because they were often in places that were almost inaccessible because of vegetation density. These areas would probably not have been searched if transmitters had not been used. Other methods of owl location (and subsequent roost site characterization) could be biased by the relative ease of locating conifer roosts by those methods.

Radio-tagging is also an effective way to distinguish individuals. Swengel and Swengel (1987) characterized 90 roost sites but did not provide any information 
regarding how individuals were identified. Using color marks, Mumford and Zusi (1958) showed that owls found repeatedly in a given area may represent different individuals. Hayward and Garton (1984) characterized 15 roosts representing three owls and I characterized 30 roosts representing five owls. Therefore, it is probable that the 90 roosts of Swengel and Swengel (1987) represent a much smaller number of owls. A later study in Wisconsin estimated that as few as 25 owls were responsible for the 623 roosts found in that study (Swengel and Swengel 1992).

A constraint of this study is sample size. Of the five individuals monitored, two were represented only once while one owl was responsible for close to half (13 of 30) of

the roost observations. A larger sample would result in a more accurate representation, but this study effectively characterized roost-sites used by a few owls in a unique environment.

\section{LITERATURE CITED}

Grove, R. A. 1985. Northern saw-whet owl winter food and roosting habits in northcentral Washington. The Murrelet 66:21-24.

Hayward, G. D. and E. O. Garton. 1984. Roost habitat selection by three small forest owls. Wilson Bull. 96:690-692.

Hill, S. R. 1986. An annotated checklist of the vascular flora of Assateague Island (Maryland and Virginia). Castanea 51:265-305.

Hosmer, D. W. and S. Lemeshow. 1989. Applied logistic regression. John Wiley and Sons, New York.

James, F. C. and H. H. Shugart Jr. 1970. A quantitative method of habitat description. Audubon Field Notes 24:727-736.

Loos, G. and P. Kerlinger. 1993. Road mortality of Saw-whet and Screech-Owls on the Cape May peninsula. Journal of Raptor Research 27:210-213. 
Mumford, R. E. and R. L. Zusi. 1958. Notes on movements, territory, and habitat of wintering Saw-whet Owls. Wilson Bull. 70:188-191.

Randle, W. and R. Austing. 1952. Ecological notes on Long-eared and Saw-whet Owls in southwestern Ohio. Ecology 33:422-426.

Swengel, S. R. and A. B. Swengel. 1987. Study of a Northern Saw-whet Owl population in Sauk County, Wisconsin. Pp. 199-208 in Biology and conservation of northern forest owls (R. W. Nero, R. J. Clark, R. J. Knapton, and R. H. Hamre, Eds.). U. S. Forest Service Gen. Tech. Report RM-142.

Swengel, S. R. and A. B. Swengel. 1992. Roosts of Northern Saw-whet Owls in southern Wisconsin. Condor 94:699-706. 
Table 3-1. Vegetation species used for roosts and frequency of use by Northern Sawwhet Owls at Assateague Island, Maryland in 1996 and 1997. Number of observations (obs.) indicates that owls were observed in the same roosts more than once. Owl ID represents the frequency of the attached transmitter (in $\mathrm{MHz}$ ).

\begin{tabular}{cccc}
\hline Owl ID & $\begin{array}{c}\text { Loblolly Pine } \\
\text { Roosts }\end{array}$ & $\begin{array}{c}\text { Myrtle } \\
\text { Roosts }\end{array}$ & $\begin{array}{c}\text { Other } \\
\text { Roosts }\end{array}$ \\
\hline 150.178 & 4 (4 obs. $)$ & $8(8$ obs. $)$ & $1(1 \text { obs. })^{\mathrm{a}}$ \\
150.217 & 6 (26 obs. & 0 & $1(1 \text { obs. })^{\mathrm{b}}$ \\
150.247 & $8(8$ obs. $)$ & 0 & $1(2 \text { obs. })^{\mathrm{c}}$ \\
150.338 & 0 & $1(1$ obs. $)$ & 0 \\
150.188 & $1(1$ obs. $)$ & 0 & 0 \\
\hline total & 19 (39 obs.) & 9 (9 obs. $)$ & 3 (4 obs. $)$ \\
\hline
\end{tabular}

${ }^{a}$ Multiflora rose (Rosa multiflora).

b Red maple (Acer rubrum).

${ }^{\mathrm{C}}$ Red cedar (Juniperus virginiana) (not measured). 
Table 3-2. Characteristics of Northern Saw-whet Owl roost sites at Assateague Island, Maryland in 1996 and 1997. Sample size of 31 for some variables is due to one owl that roosted in two places within the same tree.

\begin{tabular}{|c|c|c|c|c|c|c|}
\hline \multicolumn{2}{|l|}{ variable } & $\mathrm{n}$ & $\min$ & $\max$ & mean & SD \\
\hline \multicolumn{2}{|c|}{ Roost Height $(\mathrm{m})^{a}$} & 31 & 0.5 & 10.7 & 2.90 & 3.0 \\
\hline \multicolumn{2}{|c|}{ Roost Orientation (degrees) ${ }^{a}$} & 31 & 0 & 349 & 169.6 & 89.2 \\
\hline \multicolumn{2}{|c|}{ Distance to Trunk $(\mathrm{cm})^{a}$} & 31 & 0 & 460 & 115.6 & 132.1 \\
\hline \multicolumn{2}{|c|}{ Above Cover (\%) ${ }^{a}$} & 31 & 5 & 95 & 49.7 & 31.1 \\
\hline \multicolumn{2}{|c|}{ Below Cover (\%) ${ }^{a}$} & 31 & 5 & 95 & 24.3 & 22.5 \\
\hline \multicolumn{2}{|c|}{ Tree Height (m) } & 30 & 1.1 & 12.3 & 6.1 & 3.5 \\
\hline \multicolumn{2}{|c|}{ Canopy Cover (\%) } & 30 & 0 & 100 & 39.4 & 36.1 \\
\hline \multicolumn{2}{|c|}{ Average Canopy Height $(m)^{b}$} & 30 & 0 & 11.1 & 6.1 & 3.7 \\
\hline \multicolumn{2}{|c|}{ Average Shrub Height (cm) } & 30 & 100 & 396 & 246.6 & 66.3 \\
\hline \multicolumn{2}{|c|}{ Roost Tree DBH $(\mathrm{cm})^{\mathrm{b}}$} & 30 & 2 & 45 & 17.6 & 13.6 \\
\hline \multicolumn{2}{|c|}{ Nearest Tree $(m)^{b}$} & 30 & 2 & 7 & 4.4 & 1.7 \\
\hline \multicolumn{2}{|c|}{ Number of Stems $<2.5 \mathrm{~cm} \mathrm{DBH}^{\mathrm{b}}$} & 30 & 2 & 978 & 183.2 & 247.3 \\
\hline \multicolumn{2}{|c|}{ Number of Stems $>2.5 \mathrm{~cm} \mathrm{DBH}^{\mathrm{b}}$} & 30 & 0 & 18 & 4.7 & 5.3 \\
\hline \multirow{4}{*}{$\begin{array}{l}\text { Ground } \\
\text { Cover } \\
(\%)\end{array}$} & Shrub & 30 & 0 & 34 & 6.6 & 10.3 \\
\hline & $\begin{array}{l}\text { Leaves/Pine } \\
\text { needles }\end{array}$ & 30 & 0 & 100 & 63.5 & 31.7 \\
\hline & Sticks & 30 & 0 & 18 & 5.8 & 6.3 \\
\hline & Other & 30 & 0 & 93 & 24.6 & 32.1 \\
\hline
\end{tabular}

a Not measured at random sites.

${ }^{\mathrm{b}}$ Roost and random sites were significantly different at alpha $=0.05$. 
Table 3-3. Characteristics of Northern Saw-whet Owl random sites at Assateague Island, Maryland in 1996 and 1997.

\begin{tabular}{|c|c|c|c|c|c|c|}
\hline \multicolumn{2}{|l|}{ variable } & $\mathrm{n}$ & $\min$ & $\max$ & mean & SD \\
\hline \multicolumn{2}{|c|}{ Tree Height (m) } & 30 & 1.1 & 1.4 & 6.7 & 4.2 \\
\hline \multicolumn{2}{|c|}{ Canopy Cover (\%) } & 30 & 0 & 92 & 41.4 & 35.3 \\
\hline \multicolumn{2}{|c|}{ Average Canopy Height $(m)^{a}$} & 30 & 0 & 14.0 & 7.0 & 4.4 \\
\hline \multicolumn{2}{|c|}{ Average Shrub Height $(\mathrm{cm})$} & 30 & 60 & 460 & 243.7 & 70.2 \\
\hline \multicolumn{2}{|c|}{ Roost Tree DBH $(\mathrm{cm})^{a}$} & 30 & 1 & 42 & 15.7 & 13.0 \\
\hline \multicolumn{2}{|c|}{ Nearest Tree $(m)^{a}$} & 30 & 1.8 & 7.0 & 4.7 & 1.2 \\
\hline \multicolumn{2}{|c|}{ Number of Stems $<2.5 \mathrm{~cm} \mathrm{DBH}^{a}$} & 30 & 0 & 254 & 58.3 & 64.4 \\
\hline \multicolumn{2}{|c|}{ Number of Stems $>2.5 \mathrm{~cm} \mathrm{DBH}^{a}$} & 30 & 0 & 11 & 1.9 & 2.6 \\
\hline \multirow{4}{*}{$\begin{array}{l}\text { Ground } \\
\text { Cover } \\
\text { (\%) }\end{array}$} & Shrub & 30 & $0 \%$ & $16 \%$ & $4.7 \%$ & $6.0 \%$ \\
\hline & $\begin{array}{l}\text { Leaves/Pine } \\
\text { needles }\end{array}$ & 30 & $0 \%$ & $91 \%$ & $57.0 \%$ & $28.4 \%$ \\
\hline & Sticks & 30 & $0 \%$ & $28 \%$ & $6.5 \%$ & $8.7 \%$ \\
\hline & Other & 30 & $0 \%$ & $95 \%$ & $31.8 \%$ & $32.6 \%$ \\
\hline
\end{tabular}

${ }^{\text {a }}$ Roost and random sites were significantly different at alpha $=0.05$. 
Table 3-4. Averages and standard deviations of Northern Saw-whet Owl roost site characteristics by roost tree for myrtle and pine roosts at Assateague Island, Maryland in 1996 and 1997.

\begin{tabular}{|c|c|c|c|c|c|}
\hline \multirow{2}{*}{ Variable } & & \multicolumn{2}{|c|}{$\underline{\text { Wax Myrtle }(n=9)}$} & \multicolumn{2}{|c|}{ Loblolly Pine $(n=19)$} \\
\hline & & Mean & SD & Mean & SD \\
\hline \multicolumn{2}{|c|}{ Roost Height (m) ${ }^{a}$} & 1.0 & 0.5 & 4.0 & 3.4 \\
\hline \multicolumn{2}{|c|}{ Roost Tree Height $(\mathrm{m})^{\text {a }}$} & 2.9 & 0.9 & 7.9 & 3.1 \\
\hline \multicolumn{2}{|c|}{ Above Cover (\%) } & $50 \%$ & $30 \%$ & $50 \%$ & $30 \%$ \\
\hline \multicolumn{2}{|c|}{ Below Cover (\%) } & $30 \%$ & $20 \%$ & $20 \%$ & $20 \%$ \\
\hline \multicolumn{2}{|c|}{ Canopy Cover (\%) ${ }^{a}$} & $0 \%$ & $10 \%$ & $60 \%$ & $30 \%$ \\
\hline \multicolumn{2}{|c|}{ Average Canopy Height $(m)^{a}$} & 2.4 & 3.6 & 7.6 & 2.6 \\
\hline \multicolumn{2}{|c|}{ Average Shrub Height $(\mathrm{cm})^{a}$} & 305.1 & 56.0 & 217.0 & 50.4 \\
\hline \multicolumn{2}{|c|}{ Roost Tree DBH $(\mathrm{cm})^{a}$} & 4.4 & 1.7 & 24.9 & 11.8 \\
\hline \multicolumn{2}{|c|}{ Nearest Tree $(\mathrm{m})^{a}$} & 6.2 & 1.4 & 3.6 & 1.1 \\
\hline \multicolumn{2}{|c|}{ Number of Stems $<2.5 \mathrm{~cm} \mathrm{DBH}^{a}$} & 288.9 & 283.8 & 142.7 & 233.3 \\
\hline \multicolumn{2}{|c|}{ Number of Stems $>2.5 \mathrm{~cm} \mathrm{DBH}$} & 6.9 & 6.5 & 3.0 & 3.6 \\
\hline \multirow{4}{*}{$\begin{array}{l}\text { Ground } \\
\text { Cover } \\
(\%)\end{array}$} & Shrub & $0 \%$ & $10 \%$ & $10 \%$ & $10 \%$ \\
\hline & $\begin{array}{l}\text { Leaves/Pine } \\
\text { needles }\end{array}$ & $50 \%$ & $40 \%$ & $80 \%$ & $20 \%$ \\
\hline & Sticks ${ }^{a}$ & $0 \%$ & $0 \%$ & $10 \%$ & $10 \%$ \\
\hline & Other ${ }^{a b}$ & $50 \%$ & $40 \%$ & $10 \%$ & $20 \%$ \\
\hline \multicolumn{2}{|c|}{ Roost Orientation (degrees) } & 179.9 & 110.1 & 158.3 & 84.2 \\
\hline \multicolumn{2}{|c|}{ Distance to Trunk $(\mathrm{cm})$} & 64.4 & 88.8 & 152.1 & 146.6 \\
\hline
\end{tabular}

a Roost and random sites were significantly different at alpha $=0.05$ using Wilcoxon rank sum tests.

b The "other" category of ground cover consisted of water, sand and grass. 
Table 3-5. Comparison of Northern Saw-whet Owl roost site characteristics at Assateague Island, Maryland in 1996 and 1997 with results of other studies.

\begin{tabular}{|c|c|c|c|c|c|c|c|}
\hline Location & $\begin{array}{c}n \\
\text { roosts }\end{array}$ & $\begin{array}{c}n \\
\text { owls }\end{array}$ & $\begin{array}{l}\text { Roost Tree } \\
\text { Height }\end{array}$ & $\begin{array}{l}\text { Roost Tree } \\
\text { DBH }\end{array}$ & Perch Height & Perch Distance & Author \\
\hline Ohio & 15 & $?$ & & & $\begin{array}{l}2.4-3.0 \mathrm{~m} \\
\text { up to } 5.5 \mathrm{~m}\end{array}$ & $\begin{array}{l}1 / 2-3 / 4 \text { branch } \\
\text { length }\end{array}$ & $\begin{array}{l}\text { Randle and } \\
\text { Austing (1952) }\end{array}$ \\
\hline Idaho & 15 & 3 & $\begin{array}{l}22.6+/-3.04 \\
m\end{array}$ & $\begin{array}{l}46.0+/-8.2 \\
\mathrm{~cm}\end{array}$ & $\begin{array}{l}4.2+/-0.64 \mathrm{~m} \\
0.9-7.3 \mathrm{~m} \\
\text { (range) }\end{array}$ & & $\begin{array}{l}\text { Hayward and } \\
\text { Garton (1984) }\end{array}$ \\
\hline Washington & 8 & $?$ & & & $\begin{array}{l}1.4-5.0 \mathrm{~m} \\
\text { (range) }\end{array}$ & $\begin{array}{l}30-183 \mathrm{~cm} \\
\text { (range) }\end{array}$ & Grove (1985) \\
\hline Wisconsin & 90 & $?$ & & & $\begin{array}{l}0.69 \text { to } 7.67 \mathrm{~m} \\
\text { (range) }\end{array}$ & & $\begin{array}{l}\text { Swengel and } \\
\text { Swengel } \\
(1987)\end{array}$ \\
\hline Wisconsin & $?^{a}$ & $?$ & $\begin{array}{l}9.15+/-3.40 \\
1.5-22 \mathrm{~m} \\
\text { (range) } \\
(n=591)\end{array}$ & $\begin{array}{l}15.9+/-6.3 \\
\mathrm{~cm} 1-48 \\
\mathrm{~cm} \text { (range) } \\
(\mathrm{n}=472)\end{array}$ & $\begin{array}{l}4.05+/ 2.21 \mathrm{~m} \\
0.15-11.2 \mathrm{~m} \\
\text { (range) }(\mathrm{n}=429)\end{array}$ & $\begin{array}{l}30.9-22.2 \% \text { of } \\
\text { branch length } \\
1.3-100 \% \\
\text { (range) }(n=372)\end{array}$ & $\begin{array}{l}\text { Swengel and } \\
\text { Swengel } \\
\text { (1992) }\end{array}$ \\
\hline Maryland & 30 & 5 & $\begin{array}{l}6.1+/-3.5 \mathrm{~m} \\
1.1-12.3 \mathrm{~m} \\
\text { (range) }\end{array}$ & $\begin{array}{l}17.4+/-13.4 \\
\mathrm{~cm} 2.0- \\
45.0 \mathrm{~cm} \\
\text { (range) }\end{array}$ & $\begin{array}{l}2.9+/-3.0 \mathrm{~m} \\
0.5-10.7 \mathrm{~m} \\
\text { (range) }\end{array}$ & $\begin{array}{l}119.7+/-132.6 \\
\mathrm{~cm} \\
0-460.0 \mathrm{~cm} \\
\text { (range) }\end{array}$ & This study \\
\hline
\end{tabular}

a Sample size was variable; values are in parentheses. Total roost sample size was 623 . 


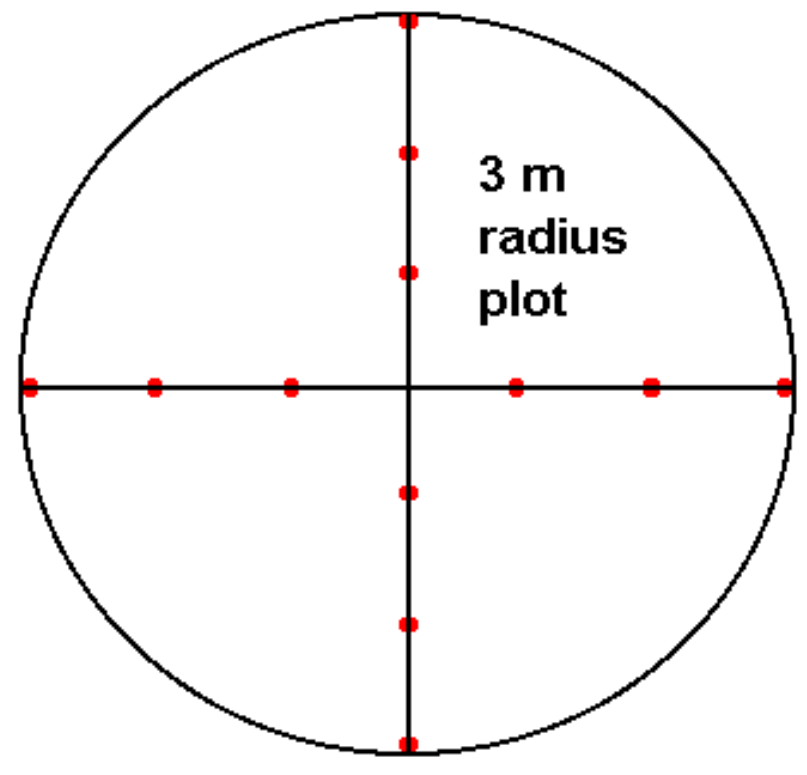

Figure 3-1. Three meter radius plot used for measurement of average canopy cover at Northern Saw-whet Owl roost sites at Assateague Island, Maryland in 1996 and 1997. Measurements were taken with a sighting tube at three points along each quadrant boundary line for a total of 12 measurements. 


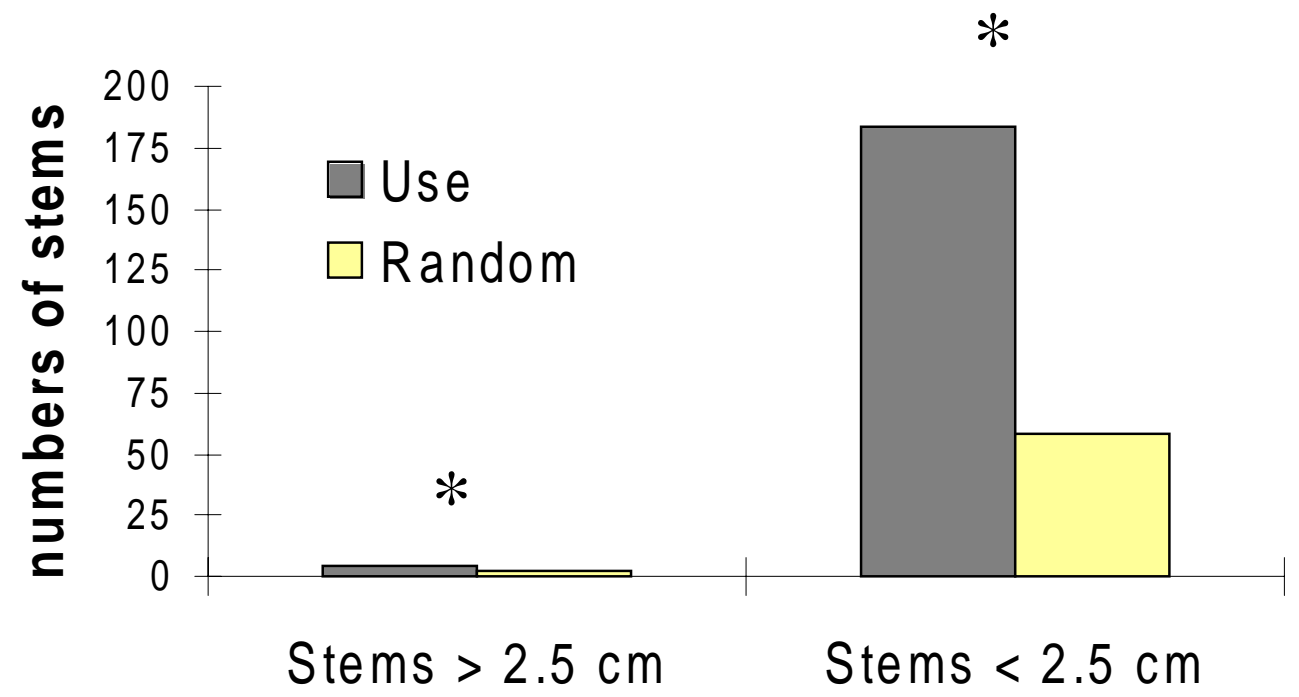

Figure 3-2. Number of stems (in two categories of DBH) in $3 \mathrm{~m}$ plots centered on roost sites and random sites at Assateague Island, Maryland in 1996 and 1997. Asterisks indicate significant differences at alpha $=0.05$.

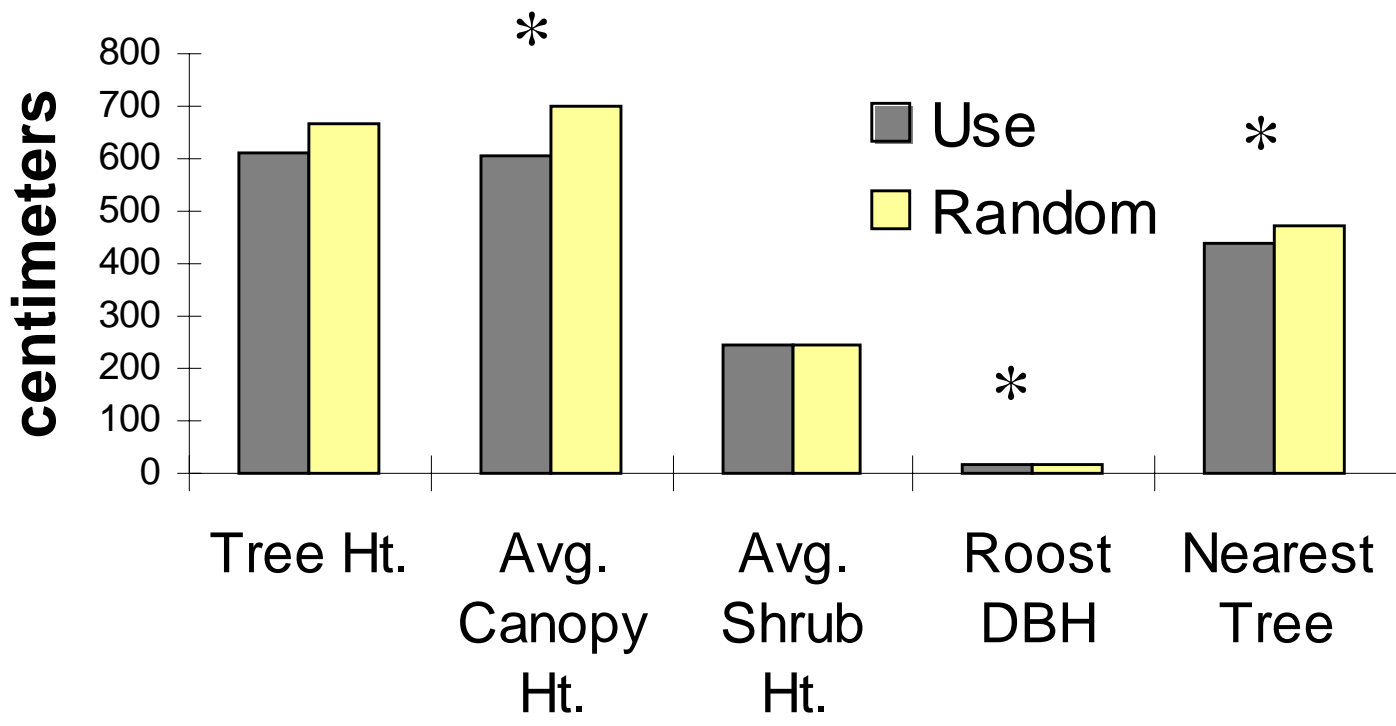

Figure 3-3. Roost site variables differentiating Northern Saw-whet Owl roost sites and random sites at Assateague Island, Maryland in 1996 and 1997. Asterisks indicate significant differences at alpha $=0.05$. 


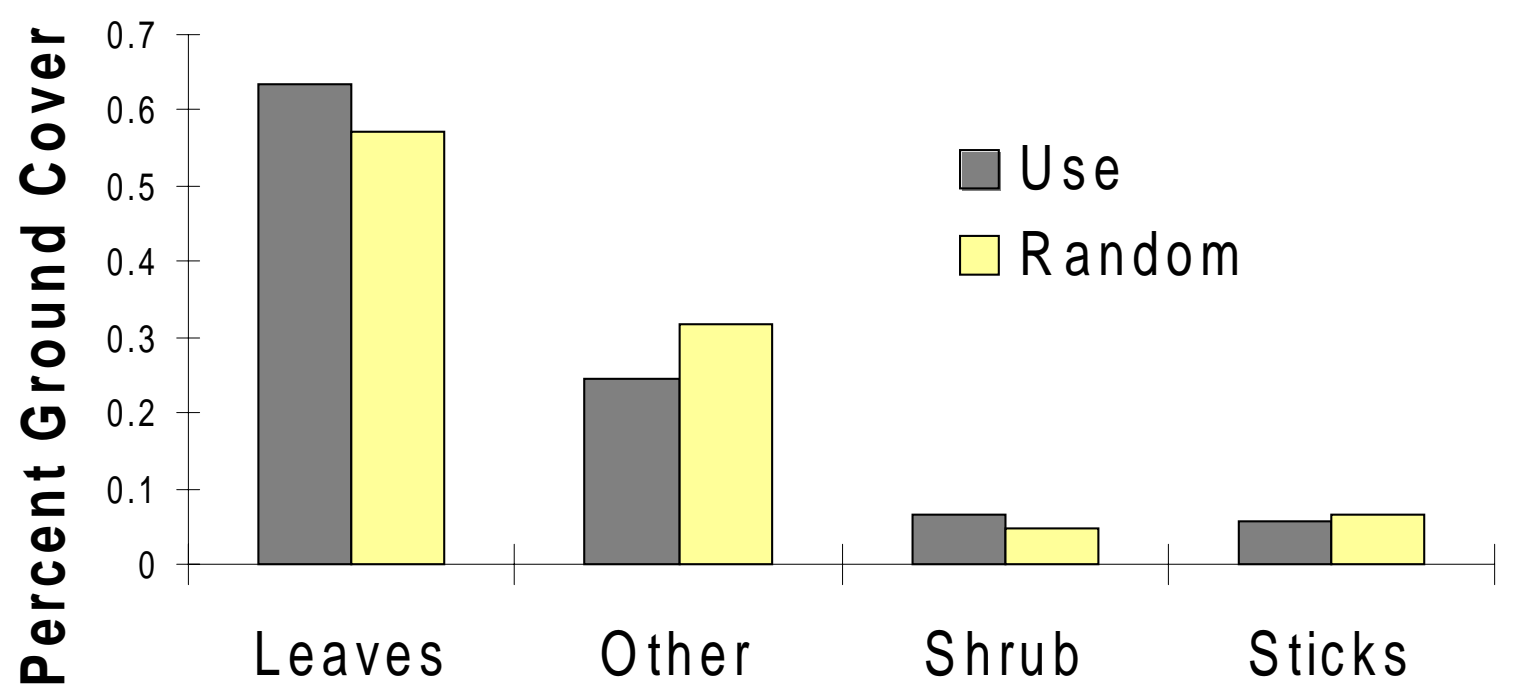

Figure 3-4. Ground cover composition in $3 \mathrm{~m}$ plots centered on roost sites and random sites at Assateague Island, Maryland in 1996 and 1997. No differences occurred between used and random sites $(P=0.05)$. The "other" category consisted of water, sand and grass. 


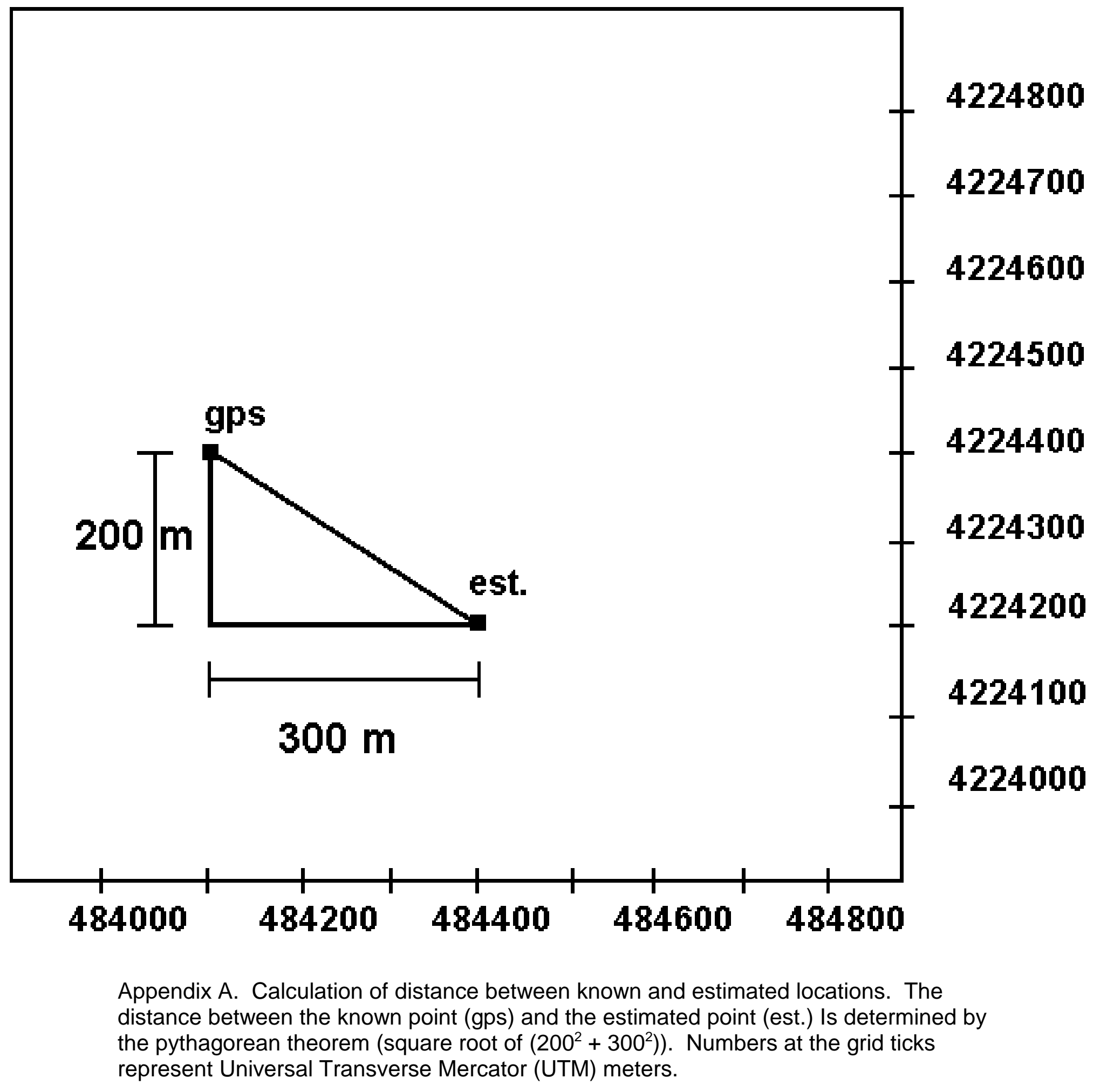


Appendix B. Plant species associations grouped into distinct habitat types from the Assateague Island National Seashore vegetation map and percentages of each main habitat type within the study area.

\begin{tabular}{|c|c|}
\hline Habitat & Description (plant associations within each habitat) \\
\hline \multirow[t]{2}{*}{ Pine Woods (6.9\%) } & Pinus taeda - Hudsonia tomentosa \\
\hline & $\begin{array}{l}\text { Pinus taeda - Myrica cerifera - Osmunda regalis - Vitus } \\
\text { rotundifolium }\end{array}$ \\
\hline Deciduous (1.4\%) & Prunus serotina - Myrica cerifera - Smilax spp. \\
\hline \multirow[t]{4}{*}{ Upland Herbaceous (10.0\%) } & Ammophilla breviligulata - Panicum \\
\hline & Spartina patens - Scirpus pungens - Solidago sempervirens \\
\hline & Dry undifferentiated grasses \\
\hline & Dead vegetation \\
\hline \multirow[t]{8}{*}{ Marsh $(36.1 \%)$} & Juncus roamerianus \\
\hline & Panicum virgatum - Spartina patens \\
\hline & Phragmites australis \\
\hline & Salicornia spp. - Sarcocomia spp. - Spartina alterniflora \\
\hline & Scirpus pungens - Fimbristylis castanea \\
\hline & Spartina alterniflora - Ascophyllum spp. \\
\hline & Spartina patens - Distichlis spicata - Borrichia frutescens \\
\hline & Typha angustifolia - Hibiscus moscheutos \\
\hline \multirow[t]{6}{*}{ Shrubland $(35.7 \%)$} & Baccharis halimifolia - Iva frutescens - Spartina patens \\
\hline & Myrica cerifera - Baccharis halimifolia - Spartina patens \\
\hline & Myrica cerifera - Hydrocotyle spp. \\
\hline & Myrica pennsylvanica - Diodateres spp. \\
\hline & $\begin{array}{l}\text { Myrica pennsylvanica - Schizachyrium scoparium - Eupatorium } \\
\text { hyssopifolium }\end{array}$ \\
\hline & Smilax glauca - Toxicodendron radicans \\
\hline Built up areas $(0.0 \%)$ & Roads and buildings etc. \\
\hline Beach $(8.6 \%)$ & Sand \\
\hline Water (1.4\%) & Standing Water and Algae \\
\hline
\end{tabular}


Appendix C. Description of vegetation variables measured in 3 meter plots at roost and random sites at Assateague Island, Maryland in 1996 and 1997.

Stem - Total number of stems, both woody and herbaceous, in the three meter plot that were less than $2.5 \mathrm{~cm}$ DBH but greater than $50 \mathrm{~cm}$ tall. This count does not take individual species into account.

ST25 - Total number of stems in the three meter plot that were greater than or equal to $2.5 \mathrm{~cm}$ but smaller than $8.0 \mathrm{~cm} \mathrm{DBH}$. This count does not take individual species into account.

Roost Tree Height - Height of the roost tree in $\mathrm{cm}$ as measured with a clinometer. If the roost tree was $<2 \mathrm{~m}$ tall, the measurement was made with a measuring tape.

Percent Canopy Cover - The sum of 12 measurements made using a sighting tube modified from James and Shugart (1970). Three measurements were taken in each section of the plot (Figure 17). A yes or no decision was made for each measurement using the crosshairs in the sighting tube regarding whether or not canopy cover was present at each spot. Then percent canopy cover was calculated by the number of yes decisions divided by 12 .

Average Canopy Height - A visual assessment was made of an area of average tree canopy height at the top of the crown. A single clinometer measurement was made using that point as a reference.

Average Shrub Height - A visual assessment was made of an area of average shrub height. A single measurement was made with a measuring tape using shrub height in that area as a reference point.

Roost Tree DBH - A measurement of the roost tree diameter at breast height made with a $\mathrm{DBH}$ measuring tape.

Distance to Nearest Tree - The closest distance from the roost tree to any neighboring tree (plant with $\geq 8 \mathrm{~cm} \mathrm{DBH}$ ) was measured and recorded. If there were no trees within 6 meters, a value of 7 meters was assigned so that statistics could be calculated for this variable.

Percent Ground Cover - Percentage of ground cover was visually estimated within 3 meter plots. Components of ground cover were short shrubs, leaves, sticks, and other (water, sand or grass). 
Appendix D. Description of vegetation variables measured only at roost sites at Assateague Island, Maryland in 1996 and 1997.

Roost Height - Measurement in centimeters of the height of the roost perch used by an owl. Measurements close to the ground were made with a measuring tape, otherwise a clinometer was used.

Distance from Trunk - When the roost was initially observed, the location on the roost branch was carefully noted so that distance could be measured using a measuring tape. When the roost height was too high to measure directly, the "zero" end of the tape was held against the trunk and distance was measured by looking up at the roost location with the measuring tape.

Orientation - A compass bearing was measured by standing at the base of the tree and pointing the compass in the direction of the roost location. 


\section{ABSTRACT \\ WINTER MOVEMENTS AND HABITAT USE OF NORTHERN SAW-WHET OWLS AT ASSATEAGUE ISLAND, MARYLAND}

\section{By John B. Churchill}

Ten Northern Saw-whet Owls were radio-tracked over two winters (1996 and 1997) at Assateague Island, Maryland. I used the fixed kernel method to calculate home range estimates for seven owls. Ninety-five percent home range sizes averaged 122.9 ha (range from 39.7 - 261.9 ha) but varied in size and shape. I also calculated adaptive kernel, harmonic mean, and minimum convex polygon home ranges for comparison of these methods. Habitat composition in $30 \%$ home ranges was compared with $95 \%$ home ranges and $30 \%$ and $95 \%$ home ranges were each compared with composition of the entire study area using compositional analysis. The comparison of $95 \%$ home range with the study area was significant $(P=0.026)$.

Forested habitat was significantly preferred and marsh and grassland habitats were significantly avoided. Habitat use at 54 telemetry location points was different from habitat available $\left(X^{2}=35.9, P=0.001, \mathrm{df}=4\right)$ with pine habitat being preferred and marsh avoided.

Roost site characteristics were measured at 30 day roosts in $3 \mathrm{~m}$ plots. Variables measured included number of stems $<2.5 \mathrm{~cm} \mathrm{DBH}$, number of stems $>2.5$ $\mathrm{cm} \mathrm{DBH}$, roost tree height, roost tree species, canopy cover, average canopy height, average shrub height, roost $\mathrm{DBH}$, distance to nearest tree, and percent ground cover. Vegetation also was measured at a random in similar habitat. Logistic regression was 
used to compare use and non-use roost plots at entry level alpha $=0.15$ and stay level alpha $=0.10$. Distance to nearest tree $(P=0.002)$ and average canopy height $(P=$ 0.01 ) were both significantly lower at use sites. Number of stems $>2.5 \mathrm{~cm}$, stems $<2.5$ $\mathrm{cm}$ and roost tree DBH were all significantly higher $(P=0.01, P=0.04$, and $P=0.03)$ at use sites. No ground cover proportions were significant.

Roosts were most often in loblolly pine forest and the more abundant myrtle swamp. High stem densities and shorter distances to nearest tree at used roost sites indicated that owls chose sites with dense cover, probably as protection from predators. Average roost height was $2.9 \mathrm{~m}(+/-3.0 \mathrm{~m} \mathrm{SD})$. Average distance to trunk was $1.2 \mathrm{~m}$ (+/- $1.3 \mathrm{~m} \mathrm{SD})$. Average percent cover above the roost was $50 \%(+/-31 \% \mathrm{SD})$ and below the roost was $24 \%(+/-23 \% \mathrm{SD})$. 